\title{
LIETUVOS KARIUOMENĖS KARININKŲ RENGIMAS (1990-2020 M.)
}

\author{
Doc. dr. Feliksas Žigaras
}

\begin{abstract}
Anotacija. Straipsnyje tiriama Lietuvos kariuomenès karininku rengimo ir ju kvalifikacijos kèlimo sistema atkūrus šalies nepriklausomybę: apžvelgiama Lietuvos karininku rengimo (karininku kursu 1990-1993 m.), Krašto apsaugos mokyklos, Generolo Jono Žemaičio Lietuvos karo akademijos veikla, atsargos karininku rengimas, aptariami kiti karininku rengimo ir ju kvalifikacijos kèlimo büdai (pvz., Lietuvos kariuomenès Generolo Adolfo Ramanausko kovinio rengimo centre, Lietuvos kariuomenés Sausumos pajègu Juozo Lukšos mokymo centre, Dr. Jono Basanavičius karo medicinos tarnybos mokymo centre) ir užsienyje.
\end{abstract}

Reikšminiai žodžiai: Karininku kursai 1990-1993 m., Krašto apsaugos mokykla, Generolo Jono Žemaičio Lietuvos karo akademija, Lietuvos kariuomenès Generolo Adolfo Ramanausko kovinio rengimo centras, Lietuvos kariuomenès Sausumos pajègu Juozo Lukšos mokymo centras, Dr. Jono Basanavičiaus karo medicinos tarnyba, karininku rengimas ir jų kvalifikacijos kèlimas užsienyje.

\section{Ivadas}

1990 m. kovo 11 d., po daugiau kaip 50 metų sovietinès okupacijos, Lietuva atgavo nepriklausomybę. Atkūrus Lietuvos nepriklausomybę, iš karto iškilo jos išsaugojimo, nacionalinio saugumo ir jo užtikrinimo problemų.

Kad ir kaip buvo sunku, Lietuvos valstybė gyvavo, tvirtejo, kūrèsi nacionalinio saugumo ir krašto apsaugos institucijos. Lietuvoje, kaip ir kitose nepriklausomybę atkūrusiose Baltijos valstybėse, nacionalinio saugumo sistema buvo plètojama kaip Europos bendro saugumo ir transatlantinès gynybos sistemų dalis.

Baltijos šalių saugumo darbotvarkę lèmé dabartinei saugumo aplinkai būdingi veiksniai: Lietuvos, Latvijos ir Estijos narystė NATO ir Europos Sajungoje ir procesai, vykstantys šiose tarptautinėse organizacijose; procesai, vykstantys Europos Sajungos ir NATO rytineje kaimynysteje, ypač tiesiogiai su Baltijos šalimis besiribojančiose Nepriklausomų valstybių sandraugos valstybėse; atsakas ị tarptautinio terorizmo iššūkị ir didèjanti masinio naikinimo ginklų platinimo grèsmè.

Lietuvos nacionalinio saugumo koncepcijos parengimo, svarstymo ir prièmimo procesas užtruko daugiau nei penkerius metus. Pagaliau 1996 m. gruodžio 19 d. Seimas prièmè Lietuvos nacionalinio saugumo pagrindu istatyma, kuris nu- 
statė Lietuvos nacionalinio saugumo užtikrinimo priemones ir būdus. Keičiantis Lietuvos vidaus ir geostrateginei aplinkai nuo 1998 iki 2020 m. lapkričio 10 d. Nacionalinio saugumo pagrindų įstatymas ir jo priedèlis net trisdešimt penkis kartus buvo keičiamas ir papildomas.

2002 m. gegužès 28 d. Lietuvos Respublikos Seimas prièmè Nacionalinio saugumo strategija, kuri sudare sąlygas užtikrinti valstybės suverenitetą, teritorini vientisumą, demokratiją, žmogaus teises ir laisves, privatumą, saugią aplinką kilus pavojui, gausejjant rizikos veiksnių, grèsmių, krizinių situacijų ir karinių konfliktų. Tuo metu Lietuva dar nebuvo tapusi NATO ir ES nare, todèl daugelis Lietuvos Respublikos nacionalinio saugumo strategijos nuostatų turejo padèti siekti narystės šiose tarptautinėse organizacijose ir jai pasirengti. Lietuvai tapus NATO ir ES nare, buvo nuspręsta Nacionalinio saugumo strategiją patobulinti (patobulinta $2005 \mathrm{~m}$. sausio 20 d.), kad ji atitiktų dabartinę situaciją ir numatytų tolesnes Lietuvos nacionalinio saugumo užtikrinimo gaires. Lietuvos Respublikos Seimas 2012 m. birželio 26 d. prièmé Nacionalinio saugumo strategijos redakciją, kuri ịtvirtino naują Lietuvos vidaus ir geostrateginę padètį, pritare sẻkmingai Lietuvos integracijai į ES, NATO ir kitas tarptautines struktūras. Reaguodamas ị pasikeitusią Lietuvos ir kaimyninio regiono saugumo situaciją ir dèl to išaugusị piliečiu švietimo nacionalinio saugumo klausimais ir jų rengimo valstybės gynybai poreikị, Lietuvos Respublikos Seimas 2017 m. sausio 17 d. prièmé naują Nacionalinio saugumo strategijos redakciją.

Lietuvos karineje strategijoje, patvirtintoje Lietuvos Respublikos krašto apsaugos ministro $2016 \mathrm{~m}$. kovo $17 \mathrm{~d}$. įsakymu Nr. V-252, pabrěžiama:

„Lietuvos sauguma užtikrina narystè NATO ir Jungtiniu Amerikos Valstiju (toliau -JAV) karinis buvimas Europoje ir regione, o naryste ES suteikia papildomy saugumo garantiju. Tiek Pietu, tiek Rytu kaimynystëje NATO ir ES susiduria su ilgalaikiais iššükiais, kurie tiesiogiai ir netiesiogiai daro ịtaka Lietuvos saugumui. Rusijos veiksmai, griaunantys taisyklèmis pagrịsta saugumo architektūra Europoje, yra svarbiausias Lietuvos sauguma mažinantis veiksnys. Lietuvos saugumo aplinka pablogèjo, o jos tolesnè raida ilgalaikeje perspektyvoje tapo sunkiau prognozuojama.

NATO reaguoja i tarptautinès saugumo aplinkos pokyčius ir stiprina pasirengima greitai atsakyti i grèsmes Aljanso nariu saugumui. Stiprejjanti kolektyvinès gynybos dimensija ir tvirtas transatlantinis ryšys užtikrina Aljanso veiksminguma kintančioje saugumo aplinkoje. Atviru duru politika, bendradarbiavimo su kitomis tarptautinèmis organizacijomis ir šalimis partnerèmis plètra, euroatlantinio ir tarptautinio saugumo stiprinimas vykdant ịvairaus pobūdžio tarptautines operacijas tebera svarbios Aljanso veiklos kryptys.

Glaudus dvišalis ir daugiašalis bendradarbiavimas gynybos srityje su JAV, Baltijos ir Šiaurès šalimis, Lenkija ir kitais sajungininkais tiesiogiai stiprina Lietuvos sauguma, prisideda prie kolektyvinès gynybos pajègumu plètojimo, JAV ir kitu NATO sajungininku karinio buvimo ir matomumo regione, didina kariniu pajegumu squveika ir pasirengima reaguoti krizès atveju. JAV įsipareigojimai užtikrinti regiono sauguma ir konkrečios priemonès igyvendinant šiuos įsipareigojimus yra 
kertinis Lietuvos saugumo veiksnys.

Lietuva aktyviai prisideda prie tarptautinès bendruomenès pastangu stiprinti Ukrainos saugumo ir gynybos sektoriaus pajegumus, remti vykdomas reformas ir taikiai išspręsti konfliktą. Bendradarbiaujant saugumo srityje su Rytu Europos, Pietu Kaukazo ir Centrinès Azijos valstybèmis plečiama saugumo erdvé, prisidedama prie demokratiniu vertybiu sklaidos, skatinamas regioninis bendradarbiavimas.

Dalyvaudama Jungtiniu Tautu Organizacijos (toliau - JTO), Europos saugumo ir bendradarbiavimo organizacijos (toliau - ESBO) ir kitu tarptautiniu organizaciju veikloje, Lietuva prisideda prie pasaulinio bei regioninio saugumo stiprinimo ir kartu prie palankios savo saugumo aplinkos kūrimo."

Tapusi NATO nare, Lietuva transformuoja savo karines pajègas kurdama modernius karinius pajègumus, siekdama tapti patikima nauja sajungininke naujame Aljanse, pasiruošusi priimti rytojaus saugumo iššūkius. NATO narių tikslas - turèti gerai parengtas ir aprūpintas, greitai perdislokuojamas mobilias pajègas, kurios būtu pasirengusios veikti kartu su tarptautinèmis Aljanso pajègomis. Lietuva yra sukaupusi nemažą regioninio karinio bendradarbiavimo patirti. Bendri projektai padeda taupyti lèšas, didina tarpusavio supratimą, santykių skaidrumą.

Tyrimo problema - vieno ar kito laikotarpio kariuomenès, jos turètos technikos ir ginkluotès, kariuomenès, kaip valdovų ir politikų planų vykdytojos, kaip vienos iš valstybės iškilimo ir nuosmukio svarbiausiujjų priežasčių (bent iki dabartinių laiku), raidos pažinimas, kuris gali padèti geriau suvokti ir tautos bei valstybės istoriją, ịvertinti jos kultūros, mokslo ir technikos, gamybos lygị, nes karo technika ir ginkluotė yra geriausias krašto ekonomikos atspindys, kariuomenès reikšmę dabartinei nepriklausomai Lietuvai ir pasirengti galimiems ateities netikètumams.

Lietuvos Respublikos krašto apsaugos ministro 2015 m. rugpjūčio 19 d. įsakymu Nr. V-849 buvo patvirtinta Lietuvos Respublikos piliečiu rengimo valstybès gynybai strategija, kurioje teigiama, kad strategijos paskirtis - „numatyti büdus užtikrinti veiksminga Lietuvos Respublikos Konstitucijoje ịtvirtintos piliečiu teisès priešintis bet kam, kas prievarta késinasi i šalies nepriklausomybę, jos teritorini vientisuma ir konstitucinę santvarka, ju teisès ir pareigos ginti valstybę nuo užsienio ginkluoto užpuolimo igyvendinima“. Todèl egzistuoja problema - kaip efektyviai paruošti veiksmingą Lietuvos karininkų rengimo sistemą.

Tyrimo objektas - Lietuvos kariuomenès karininkų rengimo ir jų kvalifikacijos kèlimo raida (1990-2020 m.).

Tyrimo tikslas - ištirti ir ịvertinti Lietuvos kariuomenès karininkų rengimo ir jų kvalifikacijos kèlimo raidą atkūrus šalies nepriklausomybę (1990-2020 m.).

\section{Tyrimo uždaviniai:}

1. Apžvelgti Lietuvos karininkų rengimo pradžią.

2. Aptarti Generolo Jono Žemaičio Lietuvos karo akademijos veiklą rengiant karininkus. 
3. Aptarti Lietuvos kariuomenès karininkų galimybes kelti kvalifikaciją Lietuvoje ir užsienyje.

Tyrimo metodai - Remiantis Lietuvos Respublikos Prezidento, Seimo, Vyriausybès, krašto apsaugos sistemos dokumentų, archyvinių šaltinių, mokslinès literatūros, internete publikuotos medžiagos ir periodinès spaudos analize, taikant istorinị ir chronologinị tyrimo metodus, darbe analizuojama Lietuvos kariuomenès karininkų rengimo ir jų kvalifikacijos kèlimo raida nepriklausomybès metais.

\section{Karininkų kursai}

1990 m. kovo 11 d. paskelbus nepriklausomybę, reikejjo ne tik organizuoti krašto apsaugą, bet ir atgaivinti sovietinès okupacijos metais sužlugdytą Lietuvos karininkų rengimą.

Balandžio 25 d. Lietuvos Respublikos Vyriausybès nutarimu buvo ịkurtas Krašto apsaugos departamentas. Šio departamento funkcijos buvo saugoti ypač svarbius Lietuvos Respublikos objektus ir vykdyti jos sienų kontrolę. Gruodžio 20 d. Lietuvos Respublikos Vyriausybès nutarimu Krašto apsaugos departamento ịsteigtuose Karininku kursuose Kaune buvo perkvalifikuojami praporščikai, jaunesnieji atsargos ir kiti buvę sovietinès kariuomenès karininkai.

Nuo 1993 m. kovo 19 d. Karininkų kursai krašto apsaugos ministro įsakymu buvo reorganizuoti ị Krašto apsaugos puskarininkiu mokyklą. 1993 m. pradžioje Karininkų kursai išleido paskutinę - VI - karininkų laidą ir prasidejjo puskarininkių tarnybos ir mokymo sistemos kūrimo darbas. Per visą savo gyvavimo laikotarpi Karininkų kursai parengè 470 karininkų.

Tačiau tolesniam karininkų rengimui ir jų kvalifikacijos tobulinimui šių kursų nepakako - trūko išsilavinusių, gerai parengtų karininkų, tad reikèjo nuolat veikiančios karininkų rengimo institucijos. Imta galvoti apie Karo mokyklos atkūrimą.

\section{Krašto apsaugos mokyklos įsteigimas}

Vadovaujantis krašto apsaugos ministro $1992 \mathrm{~m}$. vasario $25 \mathrm{~d}$. ịsakymu „Dèl Lietuvos aukštosios karo mokyklos ịkūrimo" nuspręsta ịsteigti aukštają karo mokyklą. Laikinai vadovauti naujai karinei mokymo ịstaigai Krašto apsaugos ministerijos 1992 m. vasario 21 d. įsakymu buvo paskirtas pulkininkas Algimantas Vaitkaitis.

Nuo 1992 m. kovo mèn. pradèti komplektuoti mokyklos etatai, patvirtinama mokyklos struktūra. Pradiniu mokyklos kūrimosi laikotarpiu jos administracija dirbo Profsajungų tarybos rūmuose, Gynejjų g. 7, Vilniuje.

Tačiau praejjus keturiems mėnesiams iš dalies buvo pakeistas aukštosios mokyklos statusas. Kadangi aukštujų mokyklų steigimo teisę turejo Lietuvos Respublikos Aukščiausioji Taryba, Lietuvos Respublikos Vyriausybe nutare pritarti Krašto apsaugos ministerijos siūlymui ịsteigti Krašto apsaugos akademiją ir pateikti ši klausimą svarstyti Lietuvos Respublikos Aukščiausiajai Tarybai. Tačiau tuo metu 
per tokị trumpą laiką (iki rugsèjo $1 \mathrm{~d}$.) buvo neįmanoma surinkti Vyriausybès nustatyto atitinkamo mokslininkų kontingento ir ịvykdyti kitu aukštajai mokyklai keliamų reikalavimų, todèl Krašto apsaugos ministerijai Lietuvos Respublikos Vyriausybės 1992 m. birželio 16 d. nutarimu „Dèl Krašto apsaugos akademijos steigimo“ buvo pavesta ịsteigti Krašto apsaugos mokyklą, kuri vẻliau būtu reorganizuota ị karo akademiją. 1992 m. birželio 16-oji ir laikoma oficialia Lietuvos karo akademijos įkūrimo diena.

Iš pradžių Karo mokyklą ketinta steigti Kaune, buvusiuose tarpukario Lietuvos karo mokyklos rūmuose, tačiau šie pastatai dar tebebuvo užimti sovietinès kariuomenès. Perimti Rusijos Vilniaus aukštosios priešlèktuvinès gynybos vadų radioelektronikos mokyklos (Sapiegos g. 3) turtą ir visą jos mokomają bazę, Vismaliukų poligoną pavyko iki $1992 \mathrm{~m}$. liepos $8 \mathrm{~d}$. Tą dieną buvo pasirašytas perdavimo-prièmimo aktas, Rusijos karo mokyklos vadovybė rikiuotès aikštėje nuleido Sovietų Sajungos vèliavą ir vietoj jos suplevèsavo Lietuvos trispalvė. Krašto apsaugos mokyklai ir buvo nuspręsta suteikti šias patalpas. Iš išorès - vaizdas neblogas, o viduje - baisiau nei uraganui praūžus: ką tik galèjo, sovietiniai kariškiai išsivežè, ko negalëjo išvežti - sudaužè, sulaužè, suniokojo.

Krašto apsaugos ministro 1992 m. liepos 13 d. įsakymu „Dèl Krašto apsaugos mokyklos isteigimo" buvo įsteigta Krašto apsaugos mokykla. Būtent ši data yra laikoma sisteminio karininkų rengimo pradžia, atkūrus Lietuvos nepriklausomybę.

Pagal 1992 m. liepos 15 d. ministro patvirtintus Krašto apsaugos mokyklos laikinuosius nuostatus mokykla tapo krašto apsaugos struktūriniu vienetu, pavaldžiu Krašto apsaugos ministerijai. Jai buvo iškeltas uždavinys rengti specialistus krašto apsaugos sistemai, kelti jų kvalifikaciją.

Kuriant Krašto apsaugos mokyklą buvo galvojama, kad ateityje ji būtinai taps aukštaja karo mokykla. Todèl formuojant mokyklos struktūrą buvo laikomasi aukštosios mokyklos principų: steigiamos katedros, leidžiamos mokslinès knygos, vadovèliai.

1992 m. birželio mèn. paskelbtos prièmimo ị Krašto apsaugos mokyklą sąlygos sulaukè didelio jaunimo dėmesio ir nemažai norinčiųu joje mokytis. Norinčiujų stoti dokumentus pradèta priiminèti birželio 20-ąją. Liepos 17 d. pirmajji stojamaji egzaminą - lietuvių kalbos ir literatūros (buvo rašomas rašinys), vèliau fizinio rengimo testus, užsienio kalbų egzaminą laikè 230 kandidatų (tarp jų - 81, tarnavęs kariuomenejje), visus egzaminus išlaikè 193 kandidatai.

1992 m., artejjant pirmųu mokslo metu pradžiai, buvo suformuota mokyklos administracija, nors ir ne visai sukomplektuotos, bet jau galèjo funkcionuoti daugelis tarnybų ir aštuonios katedros: Taktikos, Ginkluotès ir šaudybos, Kovos technikos, Kovinio aprūpinimo, Ryšiu ir informatikos, Filologijos, Politologijos ir Fizinio parengimo. Tačiau trūko pasienio apsaugos, specialiosios ir bendrosios taktikos dėstytojų. Liepos 28 d. buvo išrinkta Krašto apsaugos mokyklos kolegija.

1992 m. rugpjūčio 3 d. buvo sudaryti etatu sąrašai. Krašto apsaugos mokykloje prasidejjo kariūnų studijos. Buvo sudarytos dvi mokomosios kuopos: 1-oji - 
motorizuotujų šaulių ir 2-oji - pasieniečių. Daug pastangų reikèjo įdėti rengiant mokymo programas ir tvarkaraščius.

Rugpjūčio $24 \mathrm{~d}$. krašto apsaugos ministro įsakymu ị Krašto apsaugos mokyklos viršininko pareigas buvo paskirtas pulkininkas Jonas Andriškevičius, buvęs Vilniaus universiteto Karinès katedros viršininkas, Savanoriškosios krašto apsaugos tarnybos mokymo centro vadovas. Jam rugpjūčio $28 \mathrm{~d}$. buvo suteiktas pulkininko laipsnis.

Rugpjūčio 26 d. mokykloje dirbo (tarnavo) 400 žmonių, iš jų karininkų 28 (pagal etatų sąrašą - 160), puskarininkių - 11 (pagal etatų sąrašą - 103), kareivių - 64 (tarp jų buvo ir keletas savavališkai pasitraukusių iš tarnybos), kariūnų 125, civilių darbuotojų - 172 (pagal etatų sąrašą - 146), pagal galimybes buvo aprūpinta materialinėmis vertybėmis, mokykla turejjo 201 automatą ir 6 transporto priemones.

Rugpjūčio 30 d. įvyko mokyklos atidarymo ceremonija. Iškilmingos rikiuotès metu Lietuvos Respublikos Aukščiausiosios Tarybos pirmininkas Vytautas Landsbergis įteikè mokyklos (dalinio kovinę) vèliavą, kurią pašventino vyriausiasis kariuomenès kapelionas Alfonsas Svarinskas. Joje aukso raidèmis buvo išsiuvinètas šūkis „Mūsu ginklas, mūsu mokslas - Lietuvai Tèvynei“. Atidarymo iškilmèse dalyvavo Latvijos, Estijos ir NATO aukšti pareigūnai. Antakalnio kapinėse prie žuvusiųjų už Nepriklausomybę kapų kariūnai prisiekẻ ištikimai tarnauti Lietuvai.

1992 m. rugsèjo 1 d. mokslus Krašto apsaugos mokykloje pradèjo 125 kariūnai (nors buvo priimti 154, vèliau kai kurie jaunuoliai išstojo savo noru, kai ką teko pašalinti dèl nedrausmingumo), iš jų turintys vidurini išsilavinimą -84 , baigę aukštesniąsias mokyklas -17 , baigę profesines mokyklas -24 , pagal amžių: iki 20 m. $-80,20-24$ m. - 45. Svarbus kariūnų pasirengimo kokybės rodiklis buvo tai, kad net 42 procentai, t. y. 52 iš jų, buvo tarnavę kariuomenèje. Pirmajji semestrą baigè 117 kariūnų. Jie buvo mokomi pagal motorizuotujų šaulių ir valstybės sienos apsaugos tarnybos programas.

Jau pirmaji pusmetị paaiškejjo, kad ị mokyklą priimti ne patys geriausi vaikinai - atsiskleidè jų neišlavintas asociatyvusis mąstymas, negebejjimas analizuoti, greitai vertinti besikeičiančių situacijų. Taip atsitiko iš dalies dẻl skubos, neapibrèžtumo ir buitinių nesklandumų, kurie kuriant mokyklą neleido sugriežtinti atrankos. Be to, įsitikinta, kad dviejų stojamujų egzaminų - lietuvių kalbos ir fizinio pasirengimo - per maža.

Prasidejjus mokslo metams, dèstytojai susidūrè su rimta problema - Krašto apsaugos mokykla neturèjo ginkluotès, ji buvo laikoma tik kariniuose daliniuose, tad kariūnus buvo sunkiau mokyti. Dẻl buitinių sunkumų nebuvo įmanoma pakviesti dirbti mokykloje retų ir labai reikalingų karybos dalykų aukštos kvalifikacijos dèstytojų.

1993 m. kovo 13 d. krašto apsaugos ministro įsakymu karininkų, neigijusių karinio išsilavinimo, kvalifikacijai kelti buvo ịsteigtas Neakivaizdinis skyrius. Numatyta bendra studijų trukmè - 20 mènesių. Gegužès mèn. mokykloje buvo sufor- 
muota pirmoji karininkų neakivaizdininkų grupè. Ją sudare 21 neakivaizdininkas. 1993-1994 m. iš viso buvo suformuotos keturios karininkų kursų grupės, jose studijavo 96 klausytojai.

$1993 \mathrm{~m}$. rugsejjo $1 \mathrm{~d}$. ị pirmą kursą buvo priimta 110 jaunuolių, jiems buvo suteiktas kariūno laipsnis. Krašto apsaugos mokykloje jau mokèsi du kariūnų kursai, buvo sukomplektuotas pedagoginis personalas, įrengta mokymo bazè.

Lietuvos Respublikos Prezidento 1993 m. spalio 20 d. dekretu Krašto apsaugos mokyklos viršininkas plk. Jonas Andriškevičius buvo paskirtas Lietuvos kariuomenès vadu. Laikinai mokyklos viršininko pareigas pradejo eiti viršininko pavaduotojas mokymo reikalams plk. dr. Zenonas Kulys, kol krašto apsaugos ministro isakymu $1994 \mathrm{~m}$. sausio $31 \mathrm{~d}$. buvo paskirtas Krašto apsaugos mokyklos viršininku.

1993 m. galutinai suformavus Lietuvos kariuomenès struktūrą, susidarè palankios sąlygos įsteigti aukštesnio lygio karių mokymo ịstaigą, kuri rengtų krašto apsaugos sistemai aukščiausios kvalifikacijos specialistus ir galètų jiems suteikti aukštaji išsilavinimą.

\section{Lietuvos karo akademijos įsteigimas ir veikla}

1994 m. sausio 18 d. Lietuvos Respublikos Seimo nutarimu buvo isteigta Lietuvos karo akademija ir patvirtinta Lietuvos karo akademijos steigiamoji taryba, kurią sudare 35 nariai. Tarybos pirmininku buvo paskirtas krašto apsaugos ministras Linas Linkevičius. Taip Krašto apsaugos mokykla buvo reorganizuota ị Lietuvos karo akademiją.

Parengtas Lietuvos karo akademijos statutas buvo patvirtintas Lietuvos Respublikos Seimo 1994 m. gegužès 26 d. nutarimu, kuriame numatyta, kad Lietuvos karo akademija yra aukštoji mokykla - studijų ir mokslo įstaiga, skirta ugdyti Lietuvos kariuomenei aukščiausios kvalifikacijos vadus ir specialistus.

Svarbiausi Lietuvos karo akademijos uždaviniai: rengti Lietuvos Respublikos krašto apsaugos sistemai kvalifikuotus specialistus, pagal Lietuvos Respublikos Vyriausybès sutartis su kitomis šalimis - specialistus ir toms šalims; rengti mokslininkus, plètoti ir populiarinti fundamentaluji ir taikomaji karo mokslą; perkvalifikuoti krašto apsaugos sistemos specialistus karininkus ir kelti jų kvalifikaciją; rengti ir leisti mokslo darbus, vadovèlius, mokymo priemones ir kitus leidinius.

Karo akademija yra sudedamoji krašto apsaugos sistemos dalis. Taikos metu ji rengia karininkus pagal Krašto apsaugos ministerijos (toliau - KAM) užsakymą, karo ir krizių sąlygomis veikia kaip karinis dalinys, vykdo visas KAM ir Lietuvos kariuomenès vado užduotis.

Krašto apsaugos mokyklos kolegijos paskutinis poseddis įvyko $1994 \mathrm{~m}$. gegužès 30 d. Steigiamoji taryba, vadovaudamasi Statutu, 1994 m. birželio 6 d. patvirtino Lietuvos karo akademijos struktūrą, etatus, kurie mažai kuo skyrèsi nuo buvusios Karo mokyklos etatu ir struktūros, išrinko Karo akademijos rektoriumi plk. dr. Zenoną Kuli (1995 m. lapkričio 20 d. LR Prezidento dekretu plk. Z. Kuliui 
buvo suteiktas generolo laipsnis) ir jo siūlymu patvirtino prorektorius: studijoms plk. dr. Praną Jankauską, mokslui - plk. prof. habil. dr. Stasį Puškorių, kariniams reikalams - plk. 1tn. Algimantą Vyšniauską. Parengè ir patvirtino mokslo darbuotojų ir pedagogų konkurso (peratestavimo) nuostatus.

1994 m. birželio 16 d. Lietuvos heraldikos komisija patvirtino Karo akademijos baigimo ženklą. Buvo nustatyta, kad jos absolventai gali gauti trijų tipų ženklus. Jie buvo teikiami iki $2001 \mathrm{~m}$.

Vadovaudamasis Lietuvos Respublikos Seimo 1994 m. sausio 18 d. nutarimu, Seimo 1994 m. gegužès 26 d. nutarimu ir Lietuvos karo akademijos tarybos nutarimu Nr. 3, liepos 12 d. krašto apsaugos ministras L. Linkevičius įsakẻ Krašto apsaugos mokyklą reorganizuoti į Lietuvos karo akademiją.

Liepos $20 \mathrm{~d}$. buvo išleista pirmoji 111 karininku laida. 58 absolventai igijo motorizuotujų šaulių būrio vado kvalifikaciją ir tapo leitenantais, o 53 pasienio tarnybos specialistai gavo atsargos leitenanto laipsnị. Visiems buvo ịteikti aukštesniojo mokslo diplomai. 1994 m. rugpjūčio 2 d. buvo ypač svarbi Lietuvos kariuomenei. Tą dieną ministras pirmininkas Adolfas Šleževičius suteikè pirmajj karininko laipsni (leitenanto) 111 Lietuvos karo akademijos pirmosios pakopos I laidos absolventų.

Lapkričio 29 d. Akademijos mokslininkų susirinkime iš 19 narių buvo išrinkta Lietuvos karo akademijos taryba, vèliau - Akademijos senatas. Tuo metu čia dirbo 61 mokslo ir pedagoginis darbuotojas, tarp jų -6 habilituoti daktarai, 4 profesoriai, 25 daktarai, 11 docentų.

Toliau tobulinama Karo akademijos struktūra. Buvo sukomplektuotas pedagoginis personalas, įrengta mokymo bazé, leidžiami mokomieji ir metodiniai leidiniai. Akademijoje tuo metu veikè 10 katedrų (Taktikos, Ginkluotès ir šaudybos, Kovos technikos, Kovinio aprūpinimo, Ryšių ir informatikos, Vadybos, Taikomujjų mokslų, Filologijos, Politologijos, Fizinio parengimo), Mokslo centras, biblioteka, Redakcinis skyrius, kariūnų kursai, Ramovè, aprūpinimo ir aptarnavimo tarnybos. I Akademiją perejo dirbti daug Vilniaus universiteto ir Vilniaus Gedimino technikos universiteto mokslininkų.

Čia buvo rengiami dviejų specialybių - sausumos kariuomenès ir pasienio policijos - karininkai. Studijos buvo organizuojamos dviem pakopomis. I pirmają pakopą (pagal Krašto apsaugos mokyklos dvejų metų studijų programą) konkurso būdu buvo priimami Lietuvos piliečiai, turintys vidurinị išsilavinimą, mokantys valstybinę kalbą, pagal fizinị pasirengimą ir sveikatos būklę tinkantys tikrajai karo tarnybai.

Kariūnams, baigusiems pirmają studijų pakopą, buvo suteikiama būrio vado (jam lygi) kvalifikacija ir pirmasis Lietuvos kariuomenès karininko laipsnis. Pirmaisiais mokslo metais kariūnai turejjo atlikti ir privalomają karo tarnybą. I aukštesnę studijų pakopą karininkai turèjo būti priimami pagal Akademijos nuostatus ir jos sutarties su Krašto apsaugos ministerija nustatyta tvarka ne mažiau kaip po vienų tarnybos metų. 
1995 m. Akademijoje atgaivinta prieškario tradicija - suteikti pirmaji karininko laipsni, kardu paliečiant absolventui petị ir ištariant žodžius: „Be reikalo nepakelk, be garbès nenuleisk!" Nuo 2009 m. šis priesakas Akademijos viršininko i̊sakymu tapo Lietuvos karo akademijos šūkiu.

Nuo 1995 m. Akademijoje leidžiamas atkurtas žurnalas Kariūnas, aptariantis Akademijos bendruomenès gyvenimo aktualijas, studijas ir laisvalaikị.

Nuo Rugsèjo $1 \mathrm{~d}$. Akademijoje buvo studijuojama pagal čia parengtą bakalauro studijų programą (4 metų mokymas, sudaryta 6400 val. programa), atitinkančią kvalifikacinius aukštojo mokslo reikalavimus. Išplèsta Jaunojo kario rengimo kurso programa. Studijų metu kariūnai igydavo B klasès vairuotojo teises, buvo mokomi vairuoti kovinius šarvuočius.

Remiantis 1996 m. gruodžio 19 d. Lietuvos Respublikos Seimo priimtu Lietuvos Respublikos nacionalinio saugumo pagrindu ìstatymu, kuriame išdėstytos bendrosios Lietuvos gynybos nuostatos, $1997 \mathrm{~m}$. Karo akademijoje toliau tęsiamos reformos. Remiantis Vest Pointo karo akademijos patirtimi buvo suformuotos kuopos iš skirtingų kursų kariūnų, trečiakursiai paskirti ịvairių lygių vadais, o pirmakursiai ir antrakursiai tapo jų tiesioginiais pavaldiniais.

1997 m. pertvarkytas Neakivaizdinis skyrius pradejjo rengti karininkus pagal tą pačią programą. Prasidejus naujiems mokslo metams buvo pakeista kariūnų pradinio karinio rengimo programa, skiriant 12 savaičių pradinio karinio rengimo programai ir 22 savaites bendroms stažuotėms ir lauko pratyboms, pirmą kartą pradèta dèstyti Lietuvos kariuomenès istorija.

1998 m. sausio 21 d. 18 karininkų suteiktas karybos bakalauro kvalifikacinis laipsnis ir ịteikti aukštojo mokslo diplomai. Tai buvo pirmieji karininkai, Karo akademijoje gavę aukštojo mokslo diplomus.

Gegužès 5 d. Lietuvos Respublikos Seimui prièmus Lietuvos Respublikos krašto apsaugos sistemos organizavimo ir karo tarnybos ịstatyma, iš esmès pasikeitė Akademijos statusas. İstatymas nustatè, kad Karo akademija - karininkų rengimo ir kvalifikacijos kèlimo aukštoji karo mokykla - yra krašto apsaugos sistemos sudedamoji dalis, pavaldi krašto apsaugos ministrui.

Krašto apsaugos ministro įsakymu $1998 \mathrm{~m}$. lapkričio $20 \mathrm{~d}$. Lietuvos karo akademijai buvo suteiktas partizanų generolo, Lietuvos laisvės kovos sajūdžio tarybos prezidiumo pirmininko Jono Žemaičio vardas. Akademija yra Pirmojo Lietuvos Prezidento karo mokyklos istorijos ir tradiciju perèmèja ir tęsejja.

Lietuvos Respublikos Vyriausybė 1999 m. rugpjūčio 10 d. nutarimu patvirtino nauja Lietuvos karo akademijos statuta. Nustatyta, kad čia studijuoja trijų kategorijų kariai: kariūnai, karininkai klausytojai ir klausytojai. Be to, čia vykdomas Vilniaus aukštujų mokyklų studentų karinis rengimas.

Akademijos tikslas - rengti ginkluotosioms pajègoms vadus lyderius, puoselëjant Lietuvos kariuomenès tradicijas, teikiant kokybišką universitetinị ir karinị išsilavinimą, vykdant mokslinius tyrimus.

Siekiant užtikrinti stojančių jaunuolių lygias galimybes, nuo 2000 m. j̨ Karo 
akademiją pradedama priimti ir merginas. Norą studijuoti tada pareiškè 62 , tačiau stojimo testus išlaikè 9, jos ir tapo pirmosiomis kariūnėmis.

Pagal NATO standartus Akademijoje nuolat buvo pletojamas Lietuvos karybos mokslas ir vykdomas karininkų rengimo koncepcijos tobulinimas, vyko struktūriniai pokyčiai, pertvarkomas karinis rengimas ir universitetinis studijų organizavimas.

Siekiant rengti karininkus pagal NATO valstybių metodiką ir keliamus reikalavimus, reikejjo iš esmès pertvarkyti Lietuvos karo akademiją, prasidejjo reformos. Joms ịgyvendinti ministras Česlovas Stankevičius 2000 m. kovo 10 d. sudare darbo grupę ir vadovauti jai paskyrè Akademijos viršininką. Buvo parengta Akademijos plètros iki 2003 m. programa pagal kurią turèjo būti pertvarkyta Akademijos struktūra ir etatai, tobulinamos karinio rengimo programos, kad atitiktų NATO šalyse keliamus reikalavimus, parengtos naujos akademinių studijų programos, plètojama Akademijos infrastruktūra taip, kad būtų užtikrintos geresnès kariūnams ir karininkams mokymosi ir buities sąlygos.

Buvo nuspręsta nuo $2001 \mathrm{~m}$. vietoj vienos karybos bakalauro programos vykdyti pagrindines I pakopos ketverių metų universitetines studijas pagal Viešojo administravimo, Vadybos ir Tarptautiniu santykiu (politikos mokslų) studijų programas. Karinio rengimo programa, kurią išeina visi kariūnai, buvo skirta motorizuotujų pėstininkų būrio vadui rengti. Visos trys universitetinių studijų programos atitiko reikalavimus, keliamus jungiantis ị bendrają Europos švietimo erdvę: užtikrino to meto informacinių technologijų ir žinių prieinamumą, naujausia metodika paremto žinių ir ịgūdžių ịsisavinimo galimybes.

$2001 \mathrm{~m}$. vasario mèn. vykdant Akademijos reformą vèl buvo įsteigtas Mokslo centras (dèl karinių mokslinių tyrimų užsakymų stokos Mokslo centras $1997 \mathrm{~m}$. kovo 3 d. buvo panaikintas, o vietoje jo įsteigtas Mokslo skyrius, kuris $1998 \mathrm{~m}$. irgi buvo panaikintas), nes Lietuvos karo akademijai tapus universitetine aukštaja mokykla, reikèjo plètoti mokslini darbą. Kartu su Vilniaus universiteto tarptautiniu santykių institutu gruodžio mėnesị buvo ịsteigtas Strateginių tyrimų centras, su Vytauto Didžiojo universitetu - Karo istorijos centras. Birželio mėnesị įkurta Politikos mokslų katedra.

Krašto apsaugos ministras $2001 \mathrm{~m}$. vasario 15 d. įsakymu „Dél Generolo Jono Žemaičio Lietuvos karo akademijos etatu sąašo" patvirtino Akademijos padalinių (administravimo, karinio rengimo, karinio aprüpinimo, universitetinio rengimo) etatų sąrašą.

Birželio 26-ają buvo patvirtintos naujos Karo akademijos vidaus tvarkos taisyklès. Stojančiujų i ją profesiniam tinkamumui nustatyti liepos mèn. savo veiklą pradejo profesinès kandidatų i kariūnus Atrankos centras, kuris vadovavosi Didžiosios Britanijos kariuomenès nuolatinès atrankos komisijos naudojama metodika ir jos specialistų rekomendacijomis, pritaikęs jas Lietuvos sąlygoms, taip pat Akademijos, padedant kitų Lietuvos aukštujų mokyklų mokslininkams, sukurtomis originaliomis metodikomis. 
Atsižvelgiant ị kariūnų dvasinius ir religinius poreikius Karo akademijoje buvo įsteigta kapeliono institucija ir $2001 \mathrm{~m}$. spalio 19 d. iškilmingai atidaryta Šv. Anzelmo koplyčia, kurią pašventino kardinolas Audrys Juozas Bačkis.

Akademijos mokslo ir studijų sistema buvo formuojama atsižvelgiant $\underset{i}{\text { tuo- }}$ metes tarptautinès ir Lietuvos mokslo bei akademinès bendruomenès nuostatas. Akademijai nereikejjo, kaip kitoms aukštosioms mokykloms, pereiti nuo vienapakopès studijų sistemos prie dvipakopès, todèl ypatingas dèmesys buvo skiriamas studijų kokybei atsižvelgiant ị dabarties ir ateities reikalavimus. Igyvendinti šią nuostatą Karo akademijai geranoriškai padejo daugelis Lietuvos ir užsienio aukštujų mokyklų.

Minètų reformų rezultatas - Lietuvos karo akademija tapo gerai žinoma ir vertinama ne tik Baltijos šalių karo mokyklų, bet ir NATO valstybių aukštųų karininkų rengimo institucijų.

2002 m. gegužès 8 d. buvo patvirtintas naujas Karo akademijos baigimo ženklas, daug kuo primenantis prieškario Karo mokyklos ženklą.

Rugpjūčio 1 d. joje buvo isteigtas Lietuvos nuotolinio mokymo centras. Šio centro pagrindinis uždavinys - diegti ir plètoti nuotolinį mokymą Lietuvos kariuomenejje, teikti visokeriopą pagalbą karinėms mokymo įstaigoms, rengiančioms nuotolinio mokymo kursus.

2003 m. pagal Akademijos plètros programą atskirtas karinis rengimas ir akademinés studijos, ịvestas karininko (lyderio) ugdymas, integruotas i karinio ugdymo sistema. Tai - nuoseklus mokymas, ugdant būsimojo būrio vado lyderio savybes, formuojant demokratišką pilietinę pasaulejjautą. Programos tikslas - parengti karininką, pasižymintį gerais pedagoginiais gebejjimais, kuris ne tik perduotų žinias savo kariams, bet ir atliktų auklètojo, ugdytojo vaidmenį.

Nuo balandžio $1 \mathrm{~d}$. Akademijoje pasikeite karinių studijų padalinių organizacinè struktūra: vietoje karinių Taktikos, Kovinio aprūpinimo ir Fizinio rengimo katedrų buvo įsteigti Baziniai karininkų kursai, kuriuos sudarė Taktikos, Ginkluotès, Kovinès paramos, Kovinio aprūpinimo, Vado ugdymo, Fizinio rengimo sekcijos. Kapitonų kursus pakeitè Vadų ir jaunesniųjų štabo karininkų kursai.

Akademija, bendradarbiaudama su Vilniaus Gedimino technikos universiteto Antano Gustaičio aviacijos institutu (2007 m. sausio 3 d. pasirašyta sutartis), Karinėms oro pajègoms rengia orlaivių pilotus, skrydžių vadovus ir aviacijos mechanikos ir elektronikos inžinierius. Kariūnai Antano Gustaičio aviacijos institute studijuoja pagal penkias technologijos mokslų srities studijų programas: bakalauro - Aviacijos mechanikos inžinerijos, Elektronikos inžinerijos, Automatikos, magistrantūros - Orlaivių pilotavimo ir Skrydžių valdymo.

Krašto apsaugos ministro $2008 \mathrm{~m}$. gegužès $8 \mathrm{~d}$. ịsakymu buvo patvirtinta nauja Lietuvos karo akademijos plètros programa, kurios tikslas - pertvarkyti karini rengimą ir universitetini studijų organizavimą. Programos prioritetinès sritys - pirmosios ir antrosios universitetinių studijų ir karinio rengimo pakopų pertvarkymas siekiant užtikrinti kvalifikuotą ir efektyvų karininkų rengimą, Akademijos perso- 
nalo ir visų veiklos sričių optimizavimas siekiant efektyviai panaudoti žmogiškuosius, finansinius, materialinius ir kitus institucijos išteklius.

2012 m. pabaigoje priimta Lietuvos karo akademijos strategija 2013-2018 m., kurioje nurodoma, kad Akademijos misija - parengti karininką, ugdant jo lyderio savybes, intelektą, suteikiant profesinių žinių ir praktinių ịgūdžių, reikalingų tarnaujant Lietuvos kariuomeneje, NATO ir Europos Sajungoje, motyvuotą ir pasirengusi vadovauti padaliniams taikos, krizès ir karo metu tarnaujant Lietuvos valstybei.

Nuo 2012-2013 mokslo metų Karo akademija kartu su Lietuvos aukštaja jūreivystès mokykla (Klaipėdoje) ir Karinèmis jūrų pajëgomis vykdo bazini jūru pajėgų karininkų rengimą. Visiems absolventams garantuojama tarnyba Karinèse jūrų pajègose.

Krašto apsaugos ministro $2017 \mathrm{~m}$. rugsėjo $11 \mathrm{~d}$. įsakymu buvo panaikintas Universitetinių studijų institutas (įsteigtas 2011 m.), jo vadovaujamos Vadybos, Politikos, Inžinerinès vadybos, Humanitarinių mokslų, Užsienio kalbų katedros tapo pavaldžios prorektoriui mokslui ir studijoms, panaikintas Užsienio kalbų institutas (įsteigtas 2006 m.), jo funkcijos atiteko Užsienio kalbų katedrai su Vilniaus ir Kauno užsienio kalbų mokymo skyriais ir Programų rengimo ir testavimo grupe.

2018 m. balandžio 4 d. Lietuvos Respublikos Vyriausybė patvirtino naują šeštają - Karo akademijos statuto redakciją. Pagal ją, akademinę bendruomenę sudaro studentai, dèstytojai, mokslo darbuotojai, kiti tyrèjai, kariniai instruktoriai, profesoriai emeritai ir kiti darbuotojai, tiesiogiai dalyvaujantys mokslo ir (ar) studijų veikloje. Akademijoje studijuoja studentai ir klausytojai, kurie pradeda studijuoti tik su ja sudarę sutarti.

Akademijos veiklos tikslai: 1) vykdyti universitetines studijas, ugdančias karininkus, karybos ir nacionalinio saugumo specialistus, teikti moksliniais tyrimais grindžiamą šiuolaikini pažinimo ir technologijų lygị atitinkantị aukštaji universitetinị išsilavinimą, aukštojo mokslo kvalifikaciją, ugdyti visapusiškai išsilavinusią, etiškai atsakingą ir kūrybingą asmenybę; 2) darniai plètoti karybos ir nacionalinio saugumo sričių mokslini pažinimą, vykdyti tarptautinio lygio fundamentinius ir taikomuosius mokslinius tyrimus, eksperimentinę veiklą, šia veikla grindžiamas universitetines studijas, teikti aukštaji universitetinị išsilavinimą.

Siekdama nustatytų veiklos tikslų, Akademija įgyvendina šiuos uždavinius: 1) vykdo universitetines studijas; 2) vykdo karinị rengimą; 3) vykdo neformalujji švietimą; 4) atlieka nacionaliniam saugumui ir gynybai reikšmingus mokslinius tyrimus.

Krašto apsaugos ministro $2018 \mathrm{~m}$. liepos $4 \mathrm{~d}$. ịsakymu buvo ịsteigtos viršininko pavaduotojo ugdymui pareigos, įkurta Karybos katedra, Vadybos katedra pavadinta Strateginio valdymo katedra, Inžinerines vadybos katedra - Gynybos technologijų katedra, Užsienio kalbų katedra prijungta prie Humanitarinių mokslų katedros.

2020 m. sausio 1 d. Akademijoje studijavo 217 kariūnų (tarp jų - 31 mergina), 81 - bakalauro ir 71 - magistrantūros ištęstinèse studijose, 12 doktorantų. Per 
metus joje mokèsi iki 1700 ịvairių kursų klausytojų, nemažai atvykusių iš užsienio šaliu. Akademijoje dèstè (tarnavo) 16 profesorių, 22 docentai, 31 lektorius, 49 instruktoriai.

Akademijoje sèkmingai vykdomos trijų pakopų universitetinès studijos: pirmosios - bakalauro (nuo $1995 \mathrm{~m}$.), kurias baigus suteikiamas bakalauro kvalifikacinis laipsnis, antrosios - magistrantūros (nuo $2002 \mathrm{~m}$.), kurias baigus suteikiamas magistro kvalifikacinis laipsnis, ir trečiosios - doktorantūros (nuo $2012 \mathrm{~m}$.), kurias baigus suteikiamas mokslo daktaro laipsnis.

2020 m. Lietuvos karo akademijoje buvo vykdomos šios universitetiniu studiju programos: Gynybos technologijų vadybos, Nacionalinio saugumo ir gynybos, Tarptautinių santykių, Gynybos ir viešosios vadybos (ištęstinès studijos).

Antrosios pakopos - magistratūros studijos: Gynybos išteklių vadybos (ištęstinès), Gynybos studijų (ištęstinès), Karinès diplomatijos (ištęstinès).

Antrojoje pakopoje gali studijuoti tik profesinès karo tarnybos kariai, gavę LR krašto apsaugos ministro leidimą, ir pagal Krašto apsaugos ministerijos susitarimus su kitomis valstybės institucijomis kitų valstybės institucijų valstybės tarnautojai. Krašto apsaugos sistemos valstybès tarnautojai studijuoti Akademijoje siunčiami krašto apsaugos ministro arba jo ịgalioto asmens sprendimu.

2011 m. sausio 19 d. Lietuvos karo akademija su Vytauto Didžiojo, Kauno technologijos ir Klaipèdos universitetais sudare bendros veiklos sutartị ir parengé paraišką doktorantūros teisei igyti. Lietuvos Respublikos švietimo ir mokslo ministerija paraišką patenkino, todẻl nuo 2011-2012 mokslo metų buvo ịsteigta jungtinè keturių universitetų politikos mokslų doktorantūra.

Karo akademijoje studijuojantys doktorantai gilinasi ị tarptautinio ir nacionalinio saugumo, karo ir taikos, tarptautinio bendradarbiavimo saugumo ir gynybos srityse problematiką. $2020 \mathrm{~m}$. joje studijavo 12 doktorantų. $2017 \mathrm{~m}$. gruodžio $20 \mathrm{~d}$. kpt. Erikas Kaukas sėkmingai apgynè socialinių mokslų srities politikos mokslų krypties mokslo daktaro disertaciją „Rusijos karinés transformacijos poveikis Baltijos šaliu saugumo ir gynybos politikai“". Tai pirmoji disertacija, apginta Lietuvos karo akademijoje.

Siekiant užtikrinti tinkamą veiklos kokybę, Generolo Jono Žemaičio Lietuvos karo akademijoje nuo 2019 m. kuriama nauja valdymo sistema. Šiai sistemai ịdiegti sudaryta darbo grupe peržiūrèjo ir optimizavo jos veiklos valdymo procesus. Vadinamasis procesinis požiūris jai jau leido kompleksiškai ịvertinti Karo akademijos, kaip Lietuvos krašto apsaugos sistemos institucijos, veiklą ir tikslus, išanalizuoti tarpusavyje susijusius veiksmus.

Siekis sukurti veiklos kokybę užtikrinančią valdymo sistemą, įvardytas 2018-2024 m. Lietuvos karo akademijos strategijoje, atitinka Lietuvos Respublikos Vyriausybès 2018 m. gegužès 16 d. nutarimo Nr. 495 „Dèl Viešojo sektoriaus istaigu sistemos tobulinimo gairiu ir Viešojo sektoriaus istaigu sistemos tobulinimo gairiu igyvendinimo veiksmu plano patvirtinimo" nuostatas.

Per metus buvo sukurta kokybės (efektyvių darbo rezultatų) užtikrinimo sis- 
tema ir apibrezžtos bendruomenès kompetencijos, kas leidžia tobulinti jau vykstančius veiklos procesus ir planuoti tolesnius veiksmus ir ateities gaires.

Krašto apsaugos ministro $2020 \mathrm{~m}$. balandžio $1 \mathrm{~d}$. ịsakymu Nr. V-268 (ịsigaliojo rugsèjo 1 d.) iš esmès pakeista universitetinių studijų, mokslinès veiklos ir karinio rengimo struktūra: panaikintos universitetinès katedros ir Mokslo centras, jų pagrindu įsteigtos penkios mokslo grupés - Saugumo institucijų valdymo, Gynybos ekonomikos ir vadybos, Saugumo politikos, Logistikos ir gynybos technologiju vadybos, Pasaulio politikos, ikurti trys nauji centrai - Gynybos analizès, Gynybos inovacijų ir Karo mokslų informacijos ir leidybos.

$2006 \mathrm{~m}$. rugsèjo 22 d. Karo akademijoje ịkurto Užsienio kalbų instituto pagrindu 2018 m. rugsèjo 4 d. buvo ịsteigtas Užsienio kalbu centras, kurio tikslas - mokyti užsienio kalbų Lietuvos krašto apsaugos sistemos karius, valstybės tarnautojus, darbuotojus, dirbančius pagal darbo sutartis, kitų Lietuvos Respublikos statutinių institucijų pareigūnus ir valstybès tarnautojus, užsienio valstybių karius ir civilius tarnautojus, kurie turès dalyvauti daugianacionalinėse NATO, JT ar ES misijose ir operacijose, kelti kvalifikaciją užsienio valstybėse rengiant juos vykdyti tarnybines funkcijas ir užduotis, kurioms atlikti reikalingos atitinkamos užsienio kalbų žinios. Užsienio kalbu centra sudaro Vilniaus ir Kauno mokymo skyriai. 2020 m. rugsẻjo 1 d. prie Užsienio kalbų centro buvo įsteigtas Užsienio filologijos studijų skyrius.

Užsienio kalbu centro organizuojami šie kursai: bazinio, antro, trečio lygiụ anglų kalbos kursai; bazinio, antro, trečio lygių anglų kalbos kartojimo kursai; anglų kalbos kursai pagal Jungtinių Amerikos Valstijų tarptautinio karinio mokymo ir rengimo (IMET) programą; specialieji anglų kalbos kursai; parengiamieji anglu kalbos kursai karininkams, vykstantiems studijuoti ị Baltijos gynybos koledžą; kitu užsienio kalbų kursai; tarptautiniai antro lygio anglų kalbos kursai. 2020 m. rugsèjo 1 d. Užsienio kalbų centras tapo pavaldus Lietuvos karo akademijos viršininko pavaduotojui ugdymui.

Per Nepriklausomybės laikotarpị buvo sukurta tobula ir efektyviai funkcionuojanti Lietuvos kariuomenès karininkų rengimo ir jų kvalifikacijos kèlimo sistema (žr. 1 lentelę). 
1 lentelè. Lietuvos kariuomenès karininkų rengimo sistema $(2015 \mathrm{~m} .)^{1}$

\begin{tabular}{|c|c|c|c|c|c|c|c|}
\hline LYGIS & \multicolumn{2}{|c|}{$\begin{array}{l}\text { L1 } \\
\text { BAZINIS }\end{array}$} & \multicolumn{3}{|c|}{$\begin{array}{c}\text { L2 } \\
\text { TAKTINIS }\end{array}$} & $\begin{array}{l}\text { L3 } \\
\text { OPERA- } \\
\text { CINIS }\end{array}$ & \begin{tabular}{|l} 
L4 \\
STRATE- \\
GINIS
\end{tabular} \\
\hline \multirow{4}{*}{ KURSAI } & \multirow{4}{*}{$\begin{array}{l}\text { Baziniai } \\
\text { karininkų } \\
\text { rengimo } \\
\text { kursai }\end{array}$} & \multirow{4}{*}{$\begin{array}{l}\text { Specia- } \\
\text { lybès } \\
\text { kursai }\end{array}$} & \multirow{4}{*}{\begin{tabular}{|} 
Jaunesniuju \\
štabo \\
karininku \\
kursai
\end{tabular}} & \multirow{4}{*}{$\begin{array}{c}\text { Specialybès } \\
\text { kursai }\end{array}$} & $\begin{array}{l}\text { Štabo karininku } \\
\text { kursai }\end{array}$ & \multirow{4}{*}{$\begin{array}{l}\text { Vadų ir } \\
\text { generalinio } \\
\text { štabo } \\
\text { karininkų } \\
\text { kursai }\end{array}$} & \multirow{4}{*}{$\begin{array}{l}\text { Karo } \\
\text { koledžų } \\
\text { lygmens } \\
\text { kursai }\end{array}$} \\
\hline & & & & & $\begin{array}{c}\text { Vytauto Didžiojo } \\
\text { karininkų kursai } \\
\text { (LKA) }\end{array}$ & & \\
\hline & & & & & $\begin{array}{l}\text { Oro pajègų štabo } \\
\text { karininku kursai } \\
\text { (LKA) }\end{array}$ & & \\
\hline & & & & & $\begin{array}{l}\text { Jūrų pajëgų } \\
\text { štabo karininkų } \\
\text { kursai (Latvija) }\end{array}$ & & \\
\hline $\begin{array}{l}\text { MOKYMO } \\
\text { İTAIGA }\end{array}$ & \multicolumn{2}{|c|}{$\begin{array}{l}\text { Lietuvos ar užsienio } \\
\text { valstybiu karo } \\
\text { akademijos }\end{array}$} & \multicolumn{3}{|c|}{$\begin{array}{l}\text { Lietuvos ar užsienio valstybių } \\
\text { karo akademijos }\end{array}$} & $\begin{array}{l}\text { Baltijos } \\
\text { gynybos } \\
\text { koledžas }\end{array}$ & $\begin{array}{l}\text { Baltijos } \\
\text { gynybos } \\
\text { koledžas }\end{array}$ \\
\hline
\end{tabular}

Greta universitetinių studijų į Generolo Jono Žemaičio Lietuvos karo akademiją įstoję kariūnai išeina Bazinị karininko kursa, kuris skirtas pagrindinèms karybos žinioms ir igūdžiams, reikalingiems ne tik profesinèje karo tarnyboje, bet ir įvairiose civilinèse srityse, suteikti. Bazinio karininko kurso trukmè - 3,5 metų.

Galutinis rezultatas: sèkmingai Bazini karininko kursą ir universitetines studijas baigusiems kariūnams suteikiamas pirmasis karininko (leitenanto) laipsnis ir jie skiriami ị pareigas viename iš Lietuvos kariuomenès vienetų.

Be Bazinio karininko kurso, organizuojami kursai papildomoms kompetencijoms ir gebèjimams, būtiniems vadovaujant būrio dydžio (maždaug 35 kariams) kariniam padaliniui, igyti.

Krašto apsaugos ministro $2020 \mathrm{~m}$. balandžio $1 \mathrm{~d}$. ịsakymu Nr. V-268 buvo panaikinta Karybos katedra, jos pagrindu sukurta Karybos studiju grupé, kurios pagrindiniai uz̆daviniai yra:

- rengti karininkus lyderius, atitinkančius krašto apsaugos ministro patvirtintus kvalifikacinius reikalavimus, vadovaujantis Lietuvos kariuomenės vado patvirtintomis mokymo programomis;

momis;

- rengti karininkus specialistus vadovaujantis atitinkamomis kursų progra-

- rengti pratybas rezervo būrių vadams ir pagal turimus išteklius ir galimybes valstybès tarnautojams vadovaujantis atitinkamomis kursų programomis;

- pagal turimus išteklius ir galimybes padèti vesti pratybas, teikti paramą kitiems LKA padaliniams, Lietuvos kariuomenès vienetams ir Šaulių sajungai ir bendradarbiauti su užsienio šalimis;

1 Generolo Jono Žemaičio Lietuvos karo akademija [žiūrèta 2015-11-12]. Prieiga per internetą: http://www.lka.lt/lt/titulinis.html 
- vykdyti LKA profesinès karo tarnybos karių kovinị rengimą;

- planuoti ir organizuoti BKK personalo kvalifikacijos kèlimą;

- tobulinti mokymo procesą.

Karybos studiju grupę sudaro keturios sekcijos: Taktikos, Kovinès paramos ir kovinio aprūpinimo, Individualaus rengimo, Jaunesniųjų karininkų vadų mokymo, Vytauto Didžiojo karininkų ir Oro pajėgų štabo karininkų kursai.

Pagrindines funkcijas organizuojant Lietuvos karo akademijos kariūnu ugdymą vykdo Akademijos viršininko pavaduotojas ugdymui: padeda Akademijos viršininkui formuoti kariūnų ugdymo politiką; sprendžia kariūnų ugdymo klausimus; planuoja ir kontroliuoja kariūnų ugdymo veiklą; planuoja, organizuoja ir kontroliuoja Akademijos absolventų bendrujų kompetencijų kursų poreikį ir eigą; planuoja ir koordinuoja Akademijos veiklą, susijusią su jaunuolių verbavimu studijuoti Akademijoje.

\section{Kariūnų ugdymo padaliniai:}

- Fizinio rengimo centras atlieka vieną svarbiausių funkcijų - lavina būsimuosius vadus fiziškai, kad jie gebètų atlaikyti didelius krūvius, būtų atsparūs psichologiniam ir fiziniam stresui.

Fizinio rengimo centro pagrindiniai uždaviniai: organizuoti Akademijos karių ir kariūnų treniruotes; organizuoti kariūnų neformaliojo ugdymo fizinio rengimo pratybas, karių ir kariūnų varžybas, sportinę veiklą, karių ir kariūnų fizinio rengimo pratybas, testavimą pagal karinio mokymo programas ir Fizinio rengimo instruktoriaus kurso tvarkos aprašą.

- Kariūnų bataliono tikslas - ugdyti kvalifikuotus karininkus, atitinkančius šiuolaikinès kariuomenès reikalavimus. Kariūnu bataliono uždaviniai: organizuoti kasdienį karių gyvenimą, mokyti rikiuotès ir karininkystės subtilybių, sudaryti sąlygas kariūnų ugdomajai veiklai ir juos ugdyti, remti kitus Akademijos padalinius vykdant kariūnų rengimą ir neformaliają veiklą, rengti kariūnus pagal nustatytas karinio ir neformaliojo ugdymo programas.

- Kompetenciju vertinimo ir komplektavimo centro (iki $2020 \mathrm{~m}$. rugsejo 1 d. - Atrankos centras) tikslas - planuoti ir koordinuoti Akademijos veiklą, susijusią su jaunuolių pritraukimu čia studijuoti, vykdyti kandidatų, stojančių i Akademijos nuolatines bakalauro studijas ir Būrio vado kursą, atranką. Pagrindiniai Centro uždaviniai: organizuoti ir koordinuoti renginius, pristatant nuolatines bakalauro studijas Akademijoje, konsultuoti kandidatus, stojančius ị Akademijos nuolatines bakalauro studijas, vykdyti kandidatų, stojančių i Akademijos nuolatines bakalauro studijas ir Būrio vado kursą, atranką, bendradarbiauti su kitomis švietimo įstaigomis ir KAS daliniais.

- Lyderystés ir metodinio rengimo centro tikslas - planuoti, organizuoti, igyvendinti ir koordinuoti lyderio ugdymo ir metodinio rengimo programas. $\mathrm{Pa}$ grindiniai centro uždaviniai: planuoti, organizuoti ir koordinuoti kariūnų, Akademijos klausytojų, instruktorių ir dėstytojų metodinį rengimą, vesti pratybas ir praktinius užsièmimus metodinio rengimo temomis, organizuoti kursus, seminarus ir 
konferencijas metodinio rengimo temomis, Akademijos instruktorių vidinị ir išorinị mokymo proceso vertinimą, pagal kompetenciją rengti arba dalyvauti rengiant dèstomų dalykų vadovèlius ir metodines mokomąsias priemones, periodiškai atnaujinti mokymui skirtą metodinę medžiagą.

- Ramoves tikslas - burti kariūnus ir Akademijos bendruomenę, stiprinti jos estetinę ir patriotinę dvasią, puoselèti pagarbą kultūrai ir istoriniam paveldui. Pagrindiniai Ramovés uždaviniai: koordinuoti kultūrinị ir muziejininkų bendradarbiavimą su šalies aukštosiomis mokyklomis ir kitomis su tuo susijusiomis institucijomis, planuoti ir koordinuoti kariūnų neformaliojo ugdymo ir meno užsièmimus, bendradarbiauti su kitų KAS dalinių analogiškomis įstaigomis.

- Užsienio kalbu centras, kaip minèta, $2020 \mathrm{~m}$. rugsèjo $1 \mathrm{~d}$. tapo pavaldus Akademijos viršininko pavaduotojui ugdymui.

Lietuvos karo akademijoje $2018 \mathrm{~m}$. pradèta ịgyvendinti nauja 2018-2024 m. strategija. Joje sèkmingai tarpusavyje susietos penkios pamatinès strateginès plètros kryptys².

Viena prioritetiniu veiklos krypčiu Lietuvos kariuomeneje yra vado lyderio savybiu ir jo profesiniu igūdžiu ugdymas. Karo akademijos absolventas išsiskiria iš kitų Lietuvos aukštujų mokyklų absolventų šiomis kompetencijomis: karininkas lyderis - tai profesionalus, siekiantis tobulèti, gebantis priimti tinkamus sprendimus, ikvepiantis ir žinantis, kaip rūpintis savo pavaldiniais, vadas.

Būsimo karininko lyderio kompetencijų ugdymo modelis Akademijoje plètojamas tarpusavyje derinant universitetines ir karinio rengimo studijas, atsižvelgiant ị Europos Komisijos iniciatyvas dèl karininkų rengimo standarto (angl. Sectoral Qualification Framework) ir aktyviai veikiant ESDC (angl. European Security Defence Colleague) platformoje.

Lietuvos karo akademijoje vyksta intensyvus ir turiningas mokslinis, metodinis darbas, dažnai organizuojamos konferencijos, seminarai, dalyvaujama šalies ir tarptautiniuose projektuose ir kt. Akademijoje mokslinius tyrimus iki $2018 \mathrm{~m}$. koordinavo Karo mokslų institutas (KMI).

2 Pirmoji strategine kryptis - tai aukštos motyvacijos kandidatu studijuoti Lietuvos karo akademijoje paieška, agitavimas, prièmimas ị studijas, rengimas ir ugdymas, vadovaujantis Akademijos ir Lietuvos kariuomenès keliamais reikalavimais.

Antroji strategine kryptis susijusi su Lietuvos karo akademijos aukščiausio lygmens ị kariūną ir studentą orientuotomis universitetinemis ir karybos studijomis.

Trečioji strategine kryptis siejama su tarptautinius standartus atitinkančiais moksliniais tyrimais saugumo, gynybos ir karybos srityse.

Ketvirtoji strategine kryptis siejama su nuolat savo edukacinius gebejjimus tobulinančiais aukščiausios kvalifikacijos universitetinių dalykų dèstytojais, instruktoriais ir studijas remiančiu personalu.

Penktoji strategine kryptis - organizacinio veiksmingumo ir efektyvumo didinimas ne tik optimizuojant vertikaliąą organizacijos struktūrą, bet ir skatinant horizontalųji padalinių, akademinio personalo, administracijos ir kariūnų bendradarbiavimą (Generolo Jono Žemaičio Lietuvos karo akademijos strategija 2018-2024, Vilnius, 2018 m. sausio 29 d. 2019 m. redakcija, p. 8, 10-22 [žiūrèta 2019-10-20]. Prieiga per internetą: http://www.lka.lt/lt/apie-mus/dokumentai.html 
Po pertvarkos $2018 \mathrm{~m}$. vietoj KMI ịkurtas Mokslo centras, kurio tikslas vykdyti aukšto lygio nacionalinio saugumo, gynybos ir karybos tyrimus, atliepiant Lietuvos kariuomenès, KAS ir nacionalinio saugumo poreikius.

Pagrindinés moksliniu interesu sritys - Lietuvos nacionalinè saugumo ir gynybos politika, karo sociologija ir istorija, gynybos logistika ir valdymas.

Kaip minèta, $2020 \mathrm{~m}$. rugsèjo $1 \mathrm{~d}$. Mokslo centras buvo panaikintas, o jo ir keturių katedrų (Strateginio valdymo, Politikos mokslų, Gynybos technologijų, Humanitarinių mokslų) pagrindu sukurtos penkios mokslo grupès - Saugumo institucijų valdymo, Gynybos ekonomikos ir vadybos, Saugumo politikos, Logistikos ir gynybos technologijų vadybos, Pasaulio politikos, taip pat trys centrai: Gynybos analizès, Gynybos inovacijų, Karo mokslų informacijos ir leidybos.

Lietuvos karo akademija dalyvauja nacionalinių ir tarptautinių programų bei fondų skelbiamuose konkursuose, projektinëje ir konkursinëje mokslinejje veikloje.

Lietuvos karo akademijos teikiami ir vykdomi projektai prisideda prie 2018 $2024 \mathrm{~m}$. Karo akademijos strategijos trečiosios krypties - vykdyti tarptautinius standartus atitinkančius nacionaliniam saugumui ir gynybai reikšmingus mokslinius tyrimus - igyvendinimo. Siekiant mokslinių tyrimų ir mokslinès produkcijos konkurencingumo didinimo bei projektinès veiklos plètros, pritraukiant išorini mokslinių tyrimų finansavimą, vykdomi krašto apsaugos sistemai aktualūs, tarptautiniu mastu pripažinti politikos, vadybos ir tarpkryptiniai aukšto lygio moksliniai tyrimai.

Lietuvos karo akademijos mokslininkai vykdo Lietuvos Respublikos krašto apsaugos ministerijos finansuojamus krašto apsaugos sistemos mokslo tiriamuju darbų projektus (MTDP). Tai mokslinių tyrimų ir eksperimentinès plètros projektai, skirti krašto apsaugos sistemos poreikiams tenkinti.

Akademijoje vykdomi šie mokslo tiriamuju darbu projektai: 1. „Pokyčiu transatlantineje saugumo erdveje poveikio Lietuvai ir Baltijos jūros regionui tyrimai“; 2. „Laisvės kovų ir Lietuvos karybos istorija (2019-2023 m.)“; 3. „Sociologiniai Lietuvos kariuomenès raidos besikeičiančioje tarptautinio saugumo aplinkoje tyrimai (2019-2021 m.)“; 4. „Lietuvos visuomenès atsparumas ir galios vystymas pilietinei gynybai“; 5. „Transatlantinès erdvès saugumo ir gynybos procesų poveikis Lietuvos, kaip mažos valstybės, nacionaliniam saugumui ir gynybai“; 6. „Visa apimančios valstybès gynimo sistemos sukūrimo galimybių tyrimas (neginkluotos gynybos komponento integracija ị ginkluotą gynybą)“; 7. „Nuotolinio mokymo sistemų taikymas kaip ateities kario rengimo sprendinys LK“.

MTEP (moksliniai tyrimai, eksperimentinè plètra ir inovacijos) projektai: 1. „Kibernetinio saugumo kompetencijų gerinimas“ (ADVANCES). 2. „Nacionalinio kibernetinio saugumo kompetencijų žemėlapio kūrimas“ (CIBERSEK). 3. „Lietuvos mokslo tarybos remiamos veiklos krypties „Mokslininku grupiu projektai “ projektas „Inovatyviu neintervenciniu biomedicininiu tyrimu pritaikymas valdant stresa grupes dinamikoje: šauktiniu atvejis Lietuvoje“ (MIL STRES). 4. „Nacionalinès informacinio poveikio atpažinimo ir analizès ekosistemos (NAAS) sukūrimas“. 5. „Modernèjimo pokyčių raiškos įtaka pilietinès visuomenès formavimuisi: 
teorinės ịžvalgos ir praktinis pritaikomumas (PILIETIS)“. 6. „Europos Sajungos mokslinių tyrimų ir inovacijų programos „Horizontas 2020“ projektas „Specialieji pažangių mokslinių tyrimų ir technologijų projektai“" (Strategic Programs for Advanced Research and Technology in Europe - SPARTA).

Studijas remiantys projektai: nuo $2021 \mathrm{~m}$. Lietuvos karo akademijos mokslo grupès įgyvendina studijas remiančią mokslinių tyrimų programą „Mažųjų valstybių saugumas ir gynyba“, kuri apima penkis unikalius projektus (SRP): 1. „Mažųjų valstybių saugumo ir gynybos socialiniai - ekonominiai ir vadybos tyrimai“; 2. „Mažųų šalių logistikos ir gynybos technologijų vadybos tyrimai“; 3. „Globali ir nacionalinè valdysena: instituciniai, feministiniai ir komunikaciniai iššūkiai“; 4. „Mažujų valstybių saugumo ir gynybos institucijų valdymo tyrimai“; 5. „Kintanti saugumo aplinka transatlantinèje erdvejje ir mažujų Vidurio ir Rytų Europos valstybių saugumo politika“.

Gynybos politikos analizès centras populiarina ir organizuoja visuomenejje brandesnes diskusijas apie gynybą. Centro tikslas - krašto apsaugo sistemos gynybos politikos ir tarptautinio saugumo aplinkos analizè, kas vyksta kitose valstybėse ir kaip Lietuva galètu i tai reaguoti.

Gynybos inovaciju centro misija - padèti identifikuoti bei išgryninti krašto apsaugos sistemos (KAS) inovacijų poreikius ir pasitelkiant platų mokslo ir verslo partnerių tinklą tarpininkauti juos igyvendinant.

Karo mokslu informacijos ir leidybos centro tikslas - gerai sukomplektuoti paklausiais dokumentais fondą, atitinkantị studijų programas ir karininkų kvalifikacijos kèlimo uždavinius, diegti naujas informacines technologijas.

Akademijos mokslininkai ir pedagogai $1992-2020 \mathrm{~m}$. parengè apie 500 vairių sričių monografijų, mokslo studijų, žodynų, žinynų, vadovėlių, mokomujjų ir metodinių priemonių, mokslinių konferencijų pranešimų rinkinių ir kitų leidinių. Kiekvienais metais lietuvių ir anglų kalbomis išleidžiama Lietuvos metiné strategine apžvalga, Akademijos mokslo žurnalo „Karo archyvas“ tomas, mokslo žurnalas Šiuolaikinès visuomenès ugdymo veiksniai, Journal of Security and Sustainability Issues ir kt. Akademijos bibliotekos fonduose saugoma daugiau kaip 250 tūkst. egz. leidinių.

1994-2019 m. Lietuvos karo akademijoje buvo parengti 2718 absolventų: iš jų nuolatines bakalauro studijas baigè 1834 kariūnai, nuolatines magistrantūros studijas - 56 absolventai, ištęstines magistrantūros studijas - 238 absolventai (iš jų vadybos ir verslo administravimo diplomai ịteikti 44, žmonių išteklių vadybos - 72, visuomenès saugumo - 49, politikos mokslų - 73 klausytojams), ištęstines (neakivaizdines) bakalauro studijas - 590 klausytojų.

Nuo 1994 iki 2020 m. Akademija išleido 27 dieninių (nuolatinių) studijų karininkų laidas. Pirmasis karininko - leitenanto - laipsnis buvo suteiktas 1739 Lietuvos karo akademijos įvairių specializacijų absolventams ir 52 Akademijos kariūnams, baigusiems JAV sausumos pajegu akademija Vest Pointe, Karinių oro pajègų, Pakrančių apsaugos, Karinių jūrų pajègų, Danijos karališkają karinių jūrų pajègų ir kitų valstybių aukštąsias karo mokyklas (žr. 2 lentelę). 
2 lentelè. Lietuvos karo akademijos kariūnų laidos (1994-2020 m. $)^{34}$

\begin{tabular}{|c|c|c|c|c|}
\hline $\begin{array}{l}\text { Eil. } \\
\text { nr. }\end{array}$ & $\begin{array}{l}\text { Baigimo } \\
\text { metai }\end{array}$ & Laidos & $\begin{array}{c}\text { Suteiktas pirmasis } \\
\text { karininko - leitenanto - } \\
\text { laipsnis LKA absolventams } \\
\text { (skaičius) }\end{array}$ & $\begin{array}{c}\text { LKA kariūnai, mokslus baigę } \\
\text { užsienyje, kuriems suteiktas } \\
\text { pirmasis karininko - leitenanto - } \\
\text { laipsnis (skaičius) }\end{array}$ \\
\hline 1. & 1994-08-02 & I & 111 & - \\
\hline 2. & 1995-07-20 & II & 92 & - \\
\hline 3. & 1996-07-18 & III & 94 & - \\
\hline 4. & 1997-07-19 & IV & 39 & - \\
\hline 5. & 1998-07-16 & $\mathrm{V}$ & $37^{4}$ & - \\
\hline 6. & 1999-06-16 & VI & 54 & - \\
\hline 7. & 2000-06-06 & VII & 53 & - \\
\hline 8. & 2001-06-19 & VIII & 90 & - \\
\hline 9. & 2002-06-05 & IX & 110 & - \\
\hline 10. & 2003-07-03 & $\mathrm{X}$ & 122 & - \\
\hline 11. & 2004-06-30 & $\mathrm{XI}$ & 121 & - \\
\hline 12. & $2005-06-28$ & XII & 115 & 8 \\
\hline 13. & 2006-06-28 & XIII & 73 & 5 \\
\hline 14. & $2007-07-02$ & XIV & 57 & 11 \\
\hline 15. & 2008-06-28 & $\mathrm{XV}$ & 36 & 12 \\
\hline 16. & 2009-07-02 & XVI & 43 & 4 \\
\hline 17. & 2010-06-21 & XVII & 42 & 1 \\
\hline 18. & 2011-07-15 & XVIII & 45 & 2 \\
\hline 19. & 2012-07-17 & XIX & 41 & 2 \\
\hline 20. & 2013-07-19 & $\mathrm{XX}$ & 54 & 2 \\
\hline 21 & 2014-07-24 & XXI & 26 & 2 \\
\hline 22. & 2015-07-16 & XXII & 50 & 1 \\
\hline 23. & 2016-07-26 & XXIII & 42 & - \\
\hline 24. & $2017-07-28$ & XXIV & 53 & 2 \\
\hline 25. & 2018-07-26 & XXV & 41 & - \\
\hline 26. & 2019-07-23 & XXVI & 50 & - \\
\hline 27. & $2020-07-29$ & XXVII & 48 & - \\
\hline \multicolumn{3}{|c|}{ Iš viso: } & 1739 & 52 \\
\hline \multicolumn{3}{|c|}{ Iš viso: } & \multicolumn{2}{|c|}{1791} \\
\hline
\end{tabular}

3 Lentelè sudaryta remiantis Lietuvos Respublikos ministrų pirmininkų potvarkiais „Dél pirmojo karininko laipsnio suteikimo“ (1994-1996 m.), Lietuvos Respublikos prezidentų dekretais „Dèl pirmojo karininko laipsnio suteikimo"(1997-2020 m.).

4 1998-06-22 penktos kariūnų laidos II kurso 43 kariūnams, baigusiems du bakalauro rengimo programos kursus, buvo suteikta būrio vado kvalifikacija ir puskarininkio laipsnis, jie buvo pripažinti netinkamais toliau studijuoti Karo akademijoje (Lietuvos karo akademijos rektoriaus brg. gen. Z. Kulio ịsakymas „Dèl antro kurso kariūnų išleidimo“, Vilnius, 1998-07-16, Lietuvos karo akademijos archyvas, ap. 1, b. 207, 1. 20-21).

Jie parašè raštą LR prezidentui A. Adamkui. Buvo priimtas sprendimas juos siųsti ị mokomajji pulką Rukloje baigti sutrumpintus būrio vado kursus ir suteikti jiems leitenanto laipsnị. 19992000 m. 37 puskarininkiams, baigusiems karininkų kursus, buvo suteiktas pirmasis karininko leitenanto - laipsnis. 
Nuo pat Karo akademijos ịkūrimo karininkams rengti ir jų kvalifikacijai tobulinti buvo steigiami karjeros, kvalifikacijos ir kiti kursai. Nuo 2003 iki 2019 m. 28 įvairius Lietuvos karo akademijos kursus baige 3865 klausytojai. Nuo $2004 \mathrm{~m}$. Lietuvos karo akademijoje organizuojamas užsienio valstybių karininkų mokymas. 2004-2019 m. 534 klausytojai iš 18 užsienio valstybių sèkmingai čia baigè ịvairius kursus.

Vien 2019 m. Lietuvos karo akademijoje vyko 11 kursų, juos baigè 390 klausytojų: Vytauto Didžiojo karininkų kursus -83 , oro pajègų štabo karininkų -21 , karinių oro pajègų jaunesniujų karininkų -12 , būrio vado -25 , jaunesniujų karininkų vadų - 63, karinių oro pajėgų jaunesniujų karininkų - 12, valstybès tarnautoju karybos pagrindu -24 , kvalifikacijos kuopos vado - 10, instruktoriaus -60 , karininkų specialistų pagrindinio karinio parengimo - 11, tarptautinès politikos ir diplomatijos -17 , nacionalinio saugumo ir gynybos - 52 klausytojai. Juose dèste Lietuvos karo akademijos ir kariuomenès instruktoriai, lektoriai, taip pat NATO valstybių kariai ir civiliai.

Lietuvos karo akademija pasirašiusi bendradarbiavimo sutartis su Lietuvos aukštosiomis mokyklomis, istorijos ir karo muziejais, ugdymo įstaigomis, valstybès institucijomis, nevyriausybinèmis organizacijomis. Šio bendradarbiavimo tikslas - apsikeisti moksline ir metodine patirtimi, organizuoti karininkų rengimą, bendrus kultūros ir sporto renginius.

Lietuvos karo akademija jau daugelị metų bendradarbiauja su JAV, Danijos, Didžiosios Britanijos, Vokietijos, Austrijos, Prancūzijos, Kroatijos, Skandinavijos šalių, Lenkijos, Čekijos, Estijos ir Latvijos aukštosiomis karo mokyklomis. Tarptautinis bendradarbiavimas itin sustiprejo Lietuvai įstojus ị Šiaurès Atlanto sutarties organizaciją ir Europos Sajungą. Taip pat yra plètojami santykiai su kaimyninès Baltarusijos karo akademija.

Akademinis bendradarbiavimas su kitų šalių aukštojo mokslo institucijomis plètojamas ir mokslo, ir studijų kryptimis: vykdomi bendri tarptautiniai moksliniai tyrimai, dèstytojų ir studentų mainų programa, rengiamos mokslinès ir metodinės konferencijos, leidžiami bendri moksliniai leidiniai ir kt. Lietuvos karo akademijos mokslo darbuotojai ir dėstytojai aktyviai dalyvauja tarptautinių mokslo draugijų ir asociacijų veikloje. Kartu su užsienio partneriais ịgyvendinami bendri kultūriniai ir edukaciniai projektai.

Nuo 2005 m. Lietuvos karo akademija dalyvauja Erasmus (nuo 2014 m. Erasmus ${ }^{+}$) tarptautineje studijų mainų programoje: 2005-2007 m. dalyvavo Socrates veikloje, o nuo $2007 \mathrm{~m}$. - Mokymosi visą gyvenimą programoje. ES šalių karo akademijų bendradarbiavimas suaktyvèjo 2008 m., Prancūzijai iškélus iniciatyvą sukurti karinę Erasmus studijų mainų programą, kurios tikslas - ES karo mokyklų kariūnų ir jaunesniujų karininkų mainai. 2019 m. Akademija pagal Erasmus studijų mainų programą bendradarbiavo su 14 užsienio aukštujjų mokyklų.

Dalyvavimas Erasmus studijų mainų programos veikloje Lietuvos karo akademijai padeda tobulinti mokymo ir auklèjimo procesą ir užtikrinti studijų kokybę, skatina tarptautinį bendradarbiavimą ir mokslinès bei pedagoginès veiklos pažangą. 
Akademijoje lankėsi aukšto rango NATO ir kitų šalių pareigūnų - ministrų, kariuomenių ir jų padalinių vadų, karinių mokymo institucijų vadovų, politikų.

Karo akademijoje sudarytos sąlygos ne tik studijuoti, bet ir tobuletti kaip asmenybei. Čia rūpinamasi karių tautiškumu, pilietiškumu, morale, kad būtų išugdytas kultūringas žmogus, Lietuvos patriotas, o ne tik karys profesionalas. Kasmet iškilmingai pažymimos pirmojo kurso kariūnų priesaikos diena, absolventų išleistuvès, Lietuvos kariuomenès diena, Vasario 16-oji ir Kovo 11-oji, Valstybės diena, Mokslo ir žinių diena, dalyvaujama tradiciniame bėgime Gyvybès ir mirties keliu žuvusiems 1991 m. sausio 13-ąją už Lietuvos laisvę atminti, kitose šventèse ir renginiuose.

\section{Kiti karininkų rengimo ir kvalifikacijos kèlimo būdai}

\section{Atsargos karininkų rengimas}

Atsargos karininkai pagal Lietuvos Respublikos Seimo priimtą Lietuvos Respublikos karo prievolès įstatymą rengiami nuo $1996 \mathrm{~m}$., o Lietuvos karo akademijoje - nuo 1998 m. Pašaukti ị Jaunesniujjų karininkų vadų mokymus (toliau - JKVM) karo prievolininkai Krašto apsaugos savanorių pajėgų vado įsakymu skiriami ị karinio mokymo padaliniuose organizuojamus JKVM kursus. Pirmaisiais metais ị ši specialų karinio rengimo kursą įstojo 123 studentai.

Tokie kursai aukštujų mokyklų studentams buvo rengiami Lietuvos didžiojo kunigaikščio Butigeidžio dragūnų batalione Klaipeddoje, Krašto apsaugos savanorių pajègų Prisikèlimo apygardos 6-ojoje rinktinèje Šiauliuose, Generolo Jono Žemaičio Lietuvos karo akademijoje Vilniuje ir Divizijos generolo Stasio Raštikio puskarininkių mokykloje Kaune.

JKVM dalyvaujantys karo prievolininkai (toliau - klausytojai) JKVM metu Krašto apsaugos sistemos organizavimo ir karo tarnybos ịstatymo nustatyta tvarka aprūpinami apranga, maistu, jiems mokamos privalomosios pradinès karo tarnybos kariams nustatytos išmokos buitinėms išlaidoms ir premijos, taikomos socialinès garantijos. Už drausmès pažeidimus, padarytus JKVM metu, klausytojas drausminèn atsakomybėn traukiamas Lietuvos Respublikos kariuomenès drausmès statuto nustatyta tvarka.

$2001 \mathrm{~m}$. liepą Lietuvos kariuomenès vadų kursus baigè pirmoji apie 150 aukštujų mokyklų studentų laida. Trejus metus vaikinai mokèsi karo meno teorijos, dalyvavo mokymuose įvairiuose poligonuose, buvo ugdomi kaip būrio vadai. Studentams, sèkmingai atlikusiems praktiką ir išlaikiusiems kvalifikacini egzaminą, buvo suteiktas atsargos leitenanto laipsnis. Dalis jų nusprendè pasilikti tarnauti ir netrukus buvo paskirti ị karinius dalinius.

$2006 \mathrm{~m}$. dèl kariuomenès reorganizavimo Lietuvos kariuomenès vado ịsakymu studentų rengimas buvo sustabdytas, išskyrus Klaipėdą, kur Karinių jūrų pajègų mokymo centras organizuoja karinių jūrų pajègų jaunesniųjų karininkų vadų mokymus Klaipedos universiteto Jūreivystès instituto ir Lietuvos aukštosios jūrei- 
vystės mokyklos studentams, o $2012 \mathrm{~m}$. - atnaujintas, siekiant stiprinti šalies gynybinius pajègumus: rengti karininkus (būrių vadus) Lietuvos kariuomenès rezervui, jai reikalingus specialistus, ugdyti Lietuvos Respublikos pilietį, pasirengusi atlikti konstitucinę pareigą - ginklu ginti savo valstybę.

Iš viso mokymuose, skirtuose aukštujų mokyklų studentams, iki $2012 \mathrm{~m}$. buvo parengta apie 600 atsargos leitenantų.

2012 m. rugsèjo 8 d. Kaune (Divizijos generolo Stasio Raštikio Lietuvos kariuomenès mokykloje), Klaipėdoje (Lietuvos didžiojo kunigaikščio Butigeidžio dragūnų batalione) ir Vilniuje (Generolo Jono Žemaičio Lietuvos karo akademijoje) prasidejjo JKVM. Juose per du šimtus aukštujų mokyklų studentų mokèsi karybos ir siekė atsargos karininko laipsnio. Atsargos karininkų mokymai pagal pėstininkų rengimo programas buvo atnaujinti po šešerių metų pertraukos.

\section{Mokymų organizavimas}

- JKVM vyksta Lietuvos karo akademijoje Vilniuje ir Lietuvos didžiojo kunigaikščio Butigeidžio dragūnų batalione Klaipėdoje.

- Mokymu programa sudaryta vadovaujantis Lietuvos Respublikos krašto apsaugos ministro 2015 m. rugpjūčio 11 d. ịsakymu Nr. V-810 „Dél Pėstininku būrio vado ir Rezervo būrio vado mokymo reikalavimų specifikacijų patvirtinimo“" ir Lietuvos Respublikos krašto apsaugos ministro 2012 m. rugpjūčio 30 d. įsakymu Nr. V-963 „Dèl Dalimis organizuojamų Jaunesniųų karininkų vadų mokymų organizavimo ir administravimo reglamento patvirtinimo“.

- JKVM gali dalyvauti aukštujų mokyklų studentai, pareiškę norą raštu, ir klausytojai, teisès aktų nustatyta tvarka tinkantys dalyvauti mokymuose.

- Kandidatų atranką i mokymus organizuoja Lietuvos kariuomenès Karo prievolès ir komplektavimo tarnyba (žr. 3 lentelę).

3 lentelè. Jaunesniujų karininkų vadų mokymų (JKVM) programa ${ }^{5}$

\begin{tabular}{|c|c|c|c|}
\hline \multirow{2}{*}{ Mokomasis dalykas } & \multicolumn{3}{|c|}{ Valandų skaičius } \\
\cline { 2 - 4 } & I mokymo metai & II mokymo metai & III mokymo metai \\
\hline Taktika & $65\left(8^{*}\right)$ & $84\left(8^{*}\right)$ & $54\left(20^{*}\right)$ \\
\hline Ginklai ir šaudyba & $28\left(11^{*}\right)$ & $36\left(12^{*}\right)$ & 6 \\
\hline Karo inžinerija & $20\left(7^{*}\right)$ & $25\left(5^{*}\right)$ & 15 \\
\hline Ryšiai & $14\left(3^{*}\right)$ & $7\left(5^{*}\right)$ & 6 \\
\hline Karo topografija & $24\left(2^{*}\right)$ & $25\left(1^{*}\right)$ & $4\left(4^{*}\right)$ \\
\hline ChBRB sauga & $7\left(2^{*}\right)$ & & \\
\hline Karo teisė & $11\left(7^{*}\right)$ & $8\left(16^{*}\right)$ & \\
\hline
\end{tabular}

5 Generolo Jono Žemaičio Lietuvos karo akademija [žiūrèta 2020-01-12]. Prieiga per internetą: http://www.lka.lt/lt/titulinis.html 


\begin{tabular}{|c|c|c|c|}
\hline Medicina & 30 & $2\left(2^{*}\right)$ & \\
\hline Fizinis rengimas & $18\left(2^{*}\right)$ & $12\left(2^{*}\right)$ & $4\left(8^{*}\right)$ \\
\hline Logistika & 4 & $6\left(2^{*}\right)$ & $64\left(21^{*}\right)$ \\
\hline $\begin{array}{c}\text { Karinis } \\
\text { administravimas }\end{array}$ & 6 & $5\left(6^{*}\right)$ & $50\left(4^{*}\right)$ \\
\hline Lyderyste & $8\left(2^{*}\right)$ & $19\left(4^{*}\right)$ & 232 \\
\hline $\begin{array}{c}\text { Karinio mokymo } \\
\text { pagrindai }\end{array}$ & & & \\
\hline Lauko pratybos & 288 & 288 & \\
\hline
\end{tabular}

* Savarankiškas mokymasis

Aukštųjų mokyklų studentai kartą per savaitę mokosi karybos teorijos, kurią taip pat taiko ir lauko pratybose, kurios vyksta vidutiniškai dvi savaites vasaros atostogų metu. Jaunesniujų karininkų vadų mokymai - viena privalomosios pradinès karo tarnybos formų. Ją atliekantys 18-32 metų aukštujų mokyklų studentai ir absolventai, pagal tarpukario Lietuvos tradicijas vadinami kariūnais aspirantais, igyja pagrindinị karini parengimą, išmoksta veikti karinio vieneto sudètyje ir jam vadovauti.

JKVM trukmè - 1301 val. (162 dienos). Kursai tęsiasi trejus metus. Jie suskirstyti etapais. Pirmaisiais mokymosi metais klausytojai igyja bazinių karybos žinių ir igūdžių, antraisiais - mokosi vadovauti pėstininkų skyriui, trečiaisiais - pèstininkų būriui. Kiekvienų metų pabaigoje organizuojama 14 parų lauko stovykla.

Pėstininkų būrio vado kursai organizuojami trijuose miestuose - Vilniuje, Kaune, Klaipėdoje, karo medicinos gydytojo - Kaune, laivo kovinès dalies vado Klaipèdoje.

2019 m. vasario mèn. Vilniuje (Lietuvos karo akademijoje) mokèsi 242, Klaipedoje (Lietuvos didžiojo kunigaikščio Butigeidžio dragūnų batalione) - 68, Kaune (Divizijos generolo Stasio Raštikio Lietuvos kariuomenès mokykloje) - 174 JKVM klausytojai. Vien Lietuvos karo akademijos JKVM 2015-2020 m. baigè 250 absolventų.

Lietuvos karo akademijoje 2019 m. liepos 19 d. aukštujų mokyklų studentams, baigusiems JKVM, buvo suteiktas pirmasis karininko laipsnis. Daugiausia jų - 45 absolventai - mokèsi Generolo Jono Žemaičio Lietuvos karo akademijoje, 8 - Lietuvos didžiojo kunigaikščio Butigeidžio dragūnų batalione, 30 - Divizijos generolo Stasio Raštikio Lietuvos kariuomenès mokykloje ir 7 - Dr. Jono Basanavičiaus karo medicinos tarnyboje.

2020 m. liepos 17 d. Vytauto Didžiojo karo muziejaus sodelyje Kaune vyko JKVM klausytojų pirmojo karininko laipsnio suteikimo ceremonija. Karininko priesaiką davè ir Lietuvos kariuomenès rezervo karininkų gretas papildè šeštoji po mokymų atnaujinimo JKVM laida. 28 absolventai mokymus baigė Divizijos generolo Stasio Raštikio Lietuvos kariuomenès mokykloje, 46 - Generolo Jono Žemaičio Lietuvos karo akademijoje. 
Iškilmingame renginyje dalyvavo Lietuvos Respublikos krašto apsaugos ministras Raimundas Karoblis, Lietuvos kariuomenès vadui atstovaujantis Gynybos štabo viršininkas generolas majoras Gintautas Zenkevičius, Karinių oro pajègu vadas pulkininkas Dainius Guzas, Mokymo ir doktrinų valdybos vadas pulkininkas Mindaugas Steponavičius, Lietuvos kariuomenès Kauno igulos dalinių vadai, aukštujų mokyklų atstovai, JKVM karių artimieji.

JKVM jaunuoliai dalyvauja paskaitose ir igyja ryšių, topografijos, taktikos, medicinos, kitų reikalingų žinių. Taip pat ugdomos kursantų lyderio savybės, gebejjimas dirbti kolektyve. Galutinis kursų vertinimas susideda iš dviejų savaičių trukmès lauko taktiniu pratybų, kai vertinami praktiniai profesiniai ir vadovavimo igūdžiai. Sèkmingai baigusiems trejų metų kursą JKVM absolventams suteikiamas atsargos jaunesniojo karininko (leitenanto) laipsnis ir rezervo būrio vado kvalifikacija. Jie turi realias galimybes tarnauti Lietuvos kariuomeneje ir siekti karininko karjeros.

\section{Lietuvos kariuomenès Generolo Adolfo Ramanausko kovinio rengimo cen-} tras. $1991 \mathrm{~m}$. lapkričio 23 d. Krašto apsaugos departamento direktoriaus A. Butkevičiaus įsakymu Nemenčinèje įkurtas KAD Civilinès saugos tarnybos mokymo centras. Pagrindinis jo uždavinys - mokyti civilinès saugos specialistus.

$1995 \mathrm{~m}$. spalio $1 \mathrm{~d}$. Centras tapo atskiru krašto apsaugos sistemos specialistų kvalifikacijos tobulinimo centru.

$1998 \mathrm{~m}$. vasario $2 \mathrm{~d}$. krašto apsaugos ministro ịsakymu Centras pavadinamas Kariu profesinio tobulinimo centru (KPTC). Jo funkcijos buvo rūpintis karininku ir puskarininkių kvalifikacijos kèlimu. Pagrindinis uždavinys - mokyti civilinès saugos specialistus.

1998 m. vasario $9 \mathrm{~d}$. Centrui suteikiamas žymaus Lietuvos pokario rezistencinès kovos vado gen. Adolfo Ramanausko vardas ir patvirtinamas jo, kaip karinės mokymo įstaigos, ženklas.

Danijos, Didžiosios Britanijos, JAV, Švedijos, Vokietijos ir kitų Vakarų šalių vyriausybès, ginkluotosios pajègos ir tarptautinès organizacijos padejo aprūpinti KPTC mokymo bazę šiuolaikine kompiuterių technika ir mokymo priemonėmis, užsienio instruktoriai mokè ir konsultavo jo dėstytojus.

2003 m. gegužès 29 d. krašto apsaugos ministro ịsakymu Centro pavadinimas vèl keičiamas - pradedamas vadinti Generolo Adolfo Ramanausko kovinio rengimo centru. Patvirtinamas naujas Centro ženklas. Iš esmés keičiasi jo užduotys ir funkcijos.

$2007 \mathrm{~m}$. sausio $16 \mathrm{~d}$. Centrui įteikiama dalinio vèliava.

Atsižvelgiant ị Lietuvos kariuomenès transformacijos plano gaires, Generolo Adolfo Ramanausko kovinio rengimo centrui buvo keliami nauji reikalavimai:

,$<\ldots>$ Reformuoti Kovinio rengimo centra $i$ Kolektyvinio (jungtinio) rengimo centrą. Šio centro uždavinys - vykdyti kariuomenes vienetu kovinio parengimo bei kovines parengties vertinima ir teikti pasiülymus dèl kovinio rengimo tobulinimo. 
Tikslinga sujungti Kovinio rengimo centra ir Kariuomenès centrini poligona $i$ viena struktūrini padalinị ir šiuo metu Kovinio rengimo centre organizuojamu individualaus rengimo kursu vykdyma perduoti kitoms mokymo institucijoms - Generolo Jono Žemaičio Lietuvos karo akademijai ir Divizijos generolo Stasio Raštikio puskarininkiu mokyklai. Šis struktūrinis padalinys turi sudaryti salygas vykdyti bataliono grupes dydžio vieneto jungtinius mokymus. Parengti kolektyvinio rengimo standartus $<. .>$. "(Citata iš Lietuvos kariuomenès transformacijos plano gairiu, 2008).

Kovinio rengimo centro funkcija - užtikrinti įtemptą, realistišką vienetų rengimo aplinką, pagrindinị dėmesị skiriant bataliono lygiui, siekiant ugdyti kompetentingus vadus ir karius, gebančius užtikrinti sẻkmę šiuolaikiniame mūšio lauke, tinkamą operacinę aplinką, kurioje kariniai vienetai būtų rengiami pasiekti nustatytą kovinès parengties lygị ir gebètų kovoti su lanksčiai mąstančiomis, įvairiapusèmis priešininkų pajègomis.

Pagrindinis Kovinio rengimo centro tikslas - rengti karius pagal Lietuvos kariuomenès ir NATO keliamus reikalavimus. Čia nuolat rengiami ịvairūs kvalifikacijos kèlimo kursai, konferencijos, seminarai ir kiti renginiai Lietuvos kariuomenès karininkams, puskarininkiams, seržantams, igyvendinamos Baltijos regiono šalių karių mokymo programos. Klausytojai testuojami, gauna kursų baigimo pažymèjimus.

\section{Kovinio rengimo centro pagrindiniai uždaviniai:}

- sudaryti sąlygas Lietuvos kariuomenès vienetams vykdyti ịvairių lygmenų štabų mokymus naudojant kompiuterinę operacijų imitavimo sistemą JCATS (angl. Joint Conflict and Tactical Simulation);

- pritaikyti ir naudoti universalią integruotą lazerinę mūšio sistemą (UILMS) ir mokomają mūšio valdymo sistemą (I-HITS) taktinèse pratybose realesnèms mūšio sąlygoms imituoti;

- vesti trumpalaikius kovinio rengimo, taikos rèmimo operacijų, šaudymo vadovų, aplinkos apsaugos ir kitus kursus pagal Lietuvos kariuomenès poreikius;

- sudaryti operacinès aplinkos sąlygas pratybose dalyvaujantiems kariams.

Šio tikslo siekiama susitelkus ị 10 esminių užduočių, išskaidytų ị tris veiklos kryptis (angl. Lines of Effort): veiklos kryptys (LoE), esminès užduotys, galutinis rezultatas - igyvendinimą.

Centre sudarytos sąlygos Lietuvos kariuomenès vienetams vykdyti ịvairių lygmenų štabų mokymus naudojant kompiuterinę operacijų imitavimo sistemą JCA TS (Joint Conflict and Tactical Simulation). Čia sẻkmingai organizuojami štabo karininkų ir specialistų trumpalaikiai kovinio rengimo ir pasirengimo taikos rèmimo operacijoms kursai, seminarai, pratybos, kiti šalies ir tarptautiniai mokymo renginiai, KAS karių ir civilių aplinkos apsaugos mokymai. Pažymėtina, kad Centras per visus veiklos metus nuveikè nemažai. Jis kūrèsi, tobulèjo, plètojo mokymo bazę, infrastruktūrą. Nesvarbu, kad ne kartą keitèsi Centro užduotys ir prioritetai, dabar Lietuvos kariuomeneje veikia modernus, NATO standartus atitinkantis mo- 
kymo centras, turintis puikias auditorijas, kompiuterinę taktikos imitavimo sistemą, valgyklą, viešbutį, sporto ir poilsio bazę.

Centras kovinio rengimo ir aplinkos apsaugos mokymo srityje vykdo ir ịvairius tarptautinius projektus. Vyksta bendradarbiavimas su analogiškais kitų šaliu mokymo centrais. Stengiamasi praktiniame darbe perimti jų patirti. Palaikomi ryšiai su Danija, Estija, Latvija, Lenkija, Rumunija, Ukraina, Gruzija, Armėnija, Azerbaidžanu, Kazachstanu, Uzbekistanu ir kitomis šalimis.

\section{Lietuvos kariuomenès Sausumos pajègü Juozo Lukšos mokymo centras.} Sausumos pajègų Mokymo centrą ịkurti buvo numatyta Lietuvos kariuomenès transformacijos plano gairèse, patvirtintose $2007 \mathrm{~m}$. lapkričio $23 \mathrm{~d}$. krašto apsaugos ministro įsakymu.

2010 m. gruodžio 14 d., vadovaujantis Lietuvos kariuomenės vado $2010 \mathrm{~m}$. vasario 5 d. įsakymu Nr. V-82, buvo ịkurtas Sausumos pajègų vadovybės Sausumos pajègų mokymo centras (toliau - SPV SPMC). $2011 \mathrm{~m}$. liepos $1 \mathrm{~d}$., vadovaujantis krašto apsaugos ministro $2011 \mathrm{~m}$. birželio $21 \mathrm{~d}$. įsakymu Nr. 714 (buvusio SPV MC pagrindu), įsteigtas Lietuvos kariuomenès Sausumos pajegu Juozo Lukšos mokymo centras, tuo pačiu įsakymu patvirtinti jo nuostatai ir struktūra.

Oficiali Lietuvos kariuomenès Sausumos pajègų Juozo Lukšos mokymo centro įsteigimo ir vardo suteikimo ceremonija ịvyko $2011 \mathrm{~m}$. rugpjūčio 10 d., minint Juozo Lukšos 90-ąsias gimimo metines.

Lietuvos kariuomenès Sausumos pajègu Juozo Lukšos mokymo centras atskiras Lietuvos kariuomenès Sausumos pajęgų (karinis mokymo) vienetas, pavaldus Sausumos pajègų vadui.

Mokymo centro tikslas - rengti Lietuvos kariuomenès Sausumos pajėgoms (prireikus ir kitoms kariuomenès pajėgų rūšims) reikalingus specialistus ir vadus.

Lietuvos kariuomenès Sausumos pajègų Juozo Lukšos mokymo centro $u z ̌-$ daviniai yra šie: 1. organizuoti ir vykdyti Sausumos pajègų karių karini mokymą, karinių vienetų taktinị kovinị rengimą; 2. užtikrinti karinę ekspertizę manevro, karo inžinerijos, žvalgybos ir paramos ugnimi srityse.

Mokymo centras atlieka šias funkcijas:

1. planuoja, organizuoja ir vykdo Sausumos pajėgų (prireikus ir kitų kariuomenès pajègų rūšių) karinị mokymą pagal patvirtintas programas;

2. planuoja, organizuoja ir vykdo SP (prireikus ir kitu kariuomenès pajėgu rūšių) vadų karinị mokymą (taktinị rengimą);

3. planuoja, organizuoja ir vykdo Sausumos pajègų (prireikus ir kitų kariuomenès pajègų rūšių) padalinių (iki būrio dydžio) taktinị kovinị rengimą;

4. planuoja ir organizuoja Mokymo centro vykdomo karinio rengimo logistinį aprūpinimą;

5. teisès aktų nustatyta tvarka organizuoja ir atlieka Mokymo centro kursų klausytojų vertinimą, išduoda jų įvertinimą atitinkančius pažymèjimus;

6. bendradarbiauja su Lietuvos ir kitu šalių mokymo įstaigomis ir kariniais 
vienetais;

7. administruoja Mokymo centro personalą ir kursų klausytojus;

8. tobulina ir rengia Mokymo centro organizuojamų kursų programas, mokomają ir metodinę medžiagą;

9. apibendrina igytą patirtị, analizuoja ją ir pagal savo funkcines sritis diegia naujoves karinio rengimo srityje.

10. Mokymo centras gali vykdyti ir kitas ịstatymų ir kitų teisės aktų nustatytas funkcijas, susijusias su jo veikla.

Lietuvos kariuomenès Sausumos pajėgų mokymo centre organizuojami 69 skirtingi kursai daugiausia skirti Sausumos pajègų kariams, tačiau, esant poreikiui, jie atviri ir kitų Lietuvos kariuomenès pajègų kariams.

Mokymo centro kursų (jo padalinių) tikslas - rengti Sausumos pajègoms (prireikus ir kitoms kariuomenès pajėgų rūšims) reikalingus specialistus ir vadus vadovaujantis Mokymo centro kursų planu.

Kursai, skirti būsimiems štabų inžinerijos karininkams, jų asistentams ar kovinès inžinerinès paramos vienetų vadams, planuojantiems inžinerinę taktiką, organizuojantiems ir taikantiems praktikoje, suskirstyti i 4 mokomąsias dalis (inžinerinė doktrina, gynybinių operacijų inžinerinès paramos planavimas, puolamujų operacijų inžinerinès paramos planavimas ir stabilumo operacijų inžinerinès paramos planavimas).

Mokymo centre karo inžinerijos kursų ekspertai ir instruktoriai nuolat analizuoja naujausią gautą informaciją, NATO ir Lietuvos kariuomenès standartus, kitą NATO partnerių mokomają ir techninę medžiagą ir ją per pratybas perteikia ị kursus atvykusiems klausytojams.

Dr. Jono Basanavičius karo medicinos tarnybos mokymo centras. $1991 \mathrm{~m}$. vasario 22 d. atkurta Lietuvos kariuomenès Karo medicinos tarnyba Kaune plètè savo veiklą užtikrindama karių asmens ir visuomenès sveikatos priežiūrą bei medicininę ekspertizę, nacionalinių sveikatos priežiūros programų ịgyvendinimą, pajègų ir jų padalinių karinių ir kitų operacijų medicininę paramą pagal NATO standartus Lietuvoje ir už jos ribų, organizuodama karo medikų mokymą ir kvalifikacijos kèlimą, steigdama bendrus su civilinèmis sveikatos priežiūros įstaigomis pirminès sveikatos priežiūros centrus.

1999 m. vasario 11 d. buvo isteigtas Lietuvos karo medicinos tarnybos Karo medicinos mokymo centras. 2008 m. lapkričio 12 d. krašto apsaugos ministro įsakymu Karo medicinos tarnybai suteiktas Dr. Jono Basanavičiaus vardas.

Nuo pirmujų atkūrimo dienų Dr. Jono Basanavičiaus karo medicinos tarnyba aktyviai bendradarbiauja su Čekijos, Danijos, Estijos, Vokietijos, Latvijos, Olandijos, Norvegijos, Švedijos, JAV ir kitų šalių karo medikais.

Užsienio valstybès teikia Karo medicinos tarnybai ịvairių sričių materialinę ir intelektualią pagalbą rengiant ir mokant karo medicinos personalą, aprūpinant ją vaistais, medicinos įranga ir inventoriumi, tobulinat Karo medicinos tarnybą ir jos vienetų struktūrą, atitinkančią NATO reikalavimus, apmokant medicininès pa- 
ramos vienetus atlikti standartines procedūras, teikti pagalbą ekstremalių situacijų atvejais.

2012 m. buvo vykdoma Lietuvos kariuomenès Dr. Jono Basanavičiaus karo medicinos tarnybos reforma, kurios tikslas - perorientuoti karo medicinos tarnybos veiklą, stiprinant karinès medicininès paramos vienetus, kurie yra neatsiejama šalies gynybinių pajėgumų dalis. Kartu siekiama atsisakyti didžiosios dalies iki šiol Karo medicinos tarnybos teiktu pirminès sveikatos priežiūros paslaugų, perduodant šias funkcijas civilinėms sveikatos priežiūros ịstaigoms (Krašto apsauga, 2012, Nr. 12: 20).

Karo medicinos mokymo centras rengia karo medicinos gydytojus, karo medicinos gydytojo padejejus, paramedikus, medicinos instruktorius Lietuvos kariuomenei ir rezervui, kelia jų kvalifikaciją karo medicinos srityje, planuoja, organizuoja ir kontroliuoja medicininès paramos pagrindų igyvendinimą - privalomajji karių pirmosios pagalbos mokymą ir pėstininkų gelbètojų rengimą krašto apsaugos sistemai.

Šis centras - Baltijos regiono karo medicinos mokymo lyderis, puikiai vertinamas gilias karo medicinos tradicijas turinčių šalių (Danijos, JAV ir kitų). Karo medikai užtikrina kariuomenès padalinių medicininę paramą ne tik Lietuvoje, bet ir už jos ribų (tarptautinèse operacijose), padeda valstybès ir savivaldybių institucijoms ekstremalių situacijų atvejais.

\section{Karo medicinos mokymo centre organizuojami šie kursai:}

- Karo medicinos gydytojo ir karo medicinos gydytojo padejjèjo kursas;

- Rezervo karo medicinos gydytojo ir karo medicinos gydytojo padèjejjo kursas;

- Jaunesniujų karininkų vadų mokymai pagal karo medicinos gydytojo rengimo programą;

- Karo medikų, atsakingų už visuomenès sveikatos saugą ir priežiūrą, kursas;

- Paramediko kursas;

- Paramediko žinių atnaujinimo kursas;

- Paramediko karinès dalies kursas;

- Medicinos instruktoriaus kursas;

- Pažangios medicinos pagalbos sužeistiesiems karinèje aplinkoje kursas (angl. Battlefield Advanced Trauma Life Support course - BATLS);

- tarptautinis Ikistacionarinès medicinos pagalbos karinejje aplinkoje kursas (angl. Prehospital Combat Casualty Care course - PCCCC);

- tarptautinis Bazinis štabo medicinos karininko kursas (angl. Basic Staff Medical Officer course - BSMOC);

- tarptautinis Bazinis ChBRB medicinos kursas (angl. Basic CBRN Medicine course - BCBRN MED);

- tarptautinis Medicinos pagalbos organizavimo didelio masto nelaimingu atsitikimų metu karineje aplinkoje kursas (angl. Military Major Incident Medical Management and Support course-MIL MIMMS). 
Karo medicinos mokymo centras rengia Karių privalomojo pirmosios pagalbos mokymo ir Pèstininkų gelbètojų rengimo kursų dokumentus, būtinus mokymo proceso organizavimui, kursų iteisinimui, ir šiuos kursus kontroliuoja.

Karo medicinos mokymo centras organizuoja, vykdo ir kontroliuoja Medicininių individualių užduočių pratybas karo medicinos personalui, organizuoja ir vykdo individualaus medicininio rengimo prieš misijas pratybas $\mathfrak{i}$ tarptautines operacijas vykstančiam medicinos personalui, organizuoja ir kontroliuoja karo medicinos personalo stažuotes nacionalinès sveikatos sistemos sveikatos priežiūros istaigose.

Nuo 2012 m. rudens Krašto apsaugos ministerija atnaujino jaunesniųjų karininkų vadų mokymus (JKVM) aukštụjų mokyklų studentams.

JKVM tikslas - parengti aukštujų universitetinių medicinos mokyklų studentus ir absolventus vykdyti karo medicinos gydytojo (medicininès paramos vieneto vado) pareigas, kariuomenę papildyti reikalingais specialistais.

JKVM pagal karo medicinos gydytojo rengimo programą organizuoja Karo medicinos tarnyba. Pirmaisiais mokymų metais mokoma vadovaujantis Lietuvos kariuomenès vado patvirtinta JKVM mokymo programa, antraisiais ir trečiaisiais mokymų metais - Lietuvos kariuomenès vado patvirtinta JKVM programa pagal karo medicinos gydytojo rengimo programą.

JKVM gali dalyvauti aukštujų universitetinių medicinos mokyklų, medicinos fakultetų pagal medicinos programą ir odontologijos fakultetų studentai ir absolventai, pareiškę norą raštu ir teisès aktų nustatyta tvarka tinkantys dalyvauti mokymuose.

Kandidatų atranką ị JKVM organizuoja Krašto apsaugos savanorių pajègos. Šių mokymų trukmè - 160 dienų.

JKVM laikomi sėkmingai baigtais, jeigu visi galutiniai mokomujų dalykų žinių îvertinimai yra teigiami. Sėkmingai baigusiam JKVM pagal karo medicinos gydytojo rengimo programą klausytojui įteikiamas mokymų baigimo pažymejjimas, suteikiama karo medicinos gydytojo, medicinos būrio vado kvalifikacija, atsargos jaunesniojo karininko laipsnis ir jis priskiriamas parengtajam kariuomenès personalo rezervui.

Karo medicinos mokymo centras bendradarbiauja su kitomis šalies ir užsienio karo medicinos personalo rengimo bei sveikatos priežiūros institucijomis. Ypač glaudžius ryšius palaiko su Estijos, Švedijos, Jungtinès Karalystės ir JAV karo medicinos mokymo centrais. Planuojama glaudžiau bendradarbiauti su Suomija, Vokietija ir Lenkija. Tai leidžia mokyti karo medicinos personalą ir kitus karius teikti pagalbą sužeistiesiems pačiais moderniausiais ir efektyviausiais būdais, naudojant šiuolaikines priemones. Karo medicinos mokymo centras rengia tarptautinius štabo medicinos karininkų kursus ir taip ne tik gerina karo medikų sąveiką su kitų NATO šalių kolegomis, bet ir dalyvauja programoje „Partneryste taikos labui“, kviečia šioje programoje dalyvaujančių šalių karius į Medicinos centro organizuojamus kursus. 
Lietuvos kariuomenès karininkai taip pat sèkmingai kèle kvalifikacija ìvairiose kariuomenès padaliniu organizuojamose ir tarptautinèse pratybose ir dalyvaudami kituose kariniuose renginiuose.

Krašto apsaugos sistemos stiprinimu, visuomenès rengimu gynybai, karininku profesiniu rengimu, ju kvalifikacijos kélimu taip pat rūpinasi Lietuvos nevyriausybinès organizacijos: Atlanto sutarties Lietuvos bendrija, Atsargos karininku sajunga, Karių veteranų asociacija, Lietuvos atsargos karininkų sajunga, Lietuvos didžiosios kunigaikštienès Birutės karininkų šeimų moterų sajunga, Lietuvos kareivių invalidų sajungos vaikų labdaros ir paramos fondas „Gèrio spindulèlis“, Lietuvos gynybos ir saugumo pramonès asociacija, Lietuvos kariuomenès kūrèju savanorių sajunga, Lietuvos kariuomenès rezervo karių asociacija (LKRKA), Lietuvos laisvès kovotojų sąunga, Lietuvos 1941 metų birželio 22-28 dienų sukilèlių sajunga, Lietuvos karių ir veteranų asociacija, Lietuvos šaulių sajunga, Lietuvos skautija, Lietuvos šaulių studentų korporacija „Saja“, Nacionalinè gynybos pramonès asociacija, karininkų ramovès, karinè žiniasklaida ir kt.

Lietuvos kariuomenès karininku studijos užsienyje. Tik ką atkūrus Lietuvos kariuomenę buvo susirūpinta jos karininkų mokymu užsienyje ir kvalifikacijos tobulinimu. 1992 m. pirmieji Lietuvos karininkai išvyko ị ilgalaikius karinius kursus Vakarų valstybėse.

$1993 \mathrm{~m}$. JAV inicijavo karinio bendradarbiavimo ir paramos programa - ji tapo kertiniu Lietuvos ir kitų Baltijos šalių kariuomenių plètros, tobulejjimo bei laipsniško įsiliejimo ị karines Europos ir transatlantines struktūras projektu. JAV Pensilvanijos nacionaline gvardija (1993 m.) žengė pirmuosius žingsnius įgyvendindama paramos Lietuvai, Latvijai ir Estijai projektą - taip buvo pradètos dvišalio bendradarbiavimo programos „Lietuva ir Pensilvanijos valstija“, „Latvija ir Mičigano valstija“ ir „Estija ir Merilando valstija“. Tai buvo itin svarbus saugumo Šiaures ir Rytų Europoje aspektas, atsižvelgiant ị to laiko geopolitines aplinkybes ir nestabilumą Rusijoje, subyrejus Sovietų Sajungai. Šios 1993 m. Lietuvoje bei gretimose šalyse prasidejusios programos tapo tvirtu impulsu tolesniam kariniam JAV ir Europos bendradarbiavimui pletoti.

Lietuvos krašto apsaugos sistemos karininkai studijavo ir nuolat kèlè kvalifikaciją JAV karinių oro pajėgų, Pakrančių apsaugos, Karinio jūrų laivyno akademijose, Kariuomenės oro gynybos artilerijos mokykloje, Karinių jūrų pajėgų koledže, Fort Lee bazèje (Virdžinijos valstija), Sausumos pajègų karo koledže, Kariuomenès manevrinio palaikymo centre, NATO oro pajègų vadavieteje Ramšteine Vokietijoje, NATO mokykloje Oberamergau (Bavarijos žemè, Vokietija), NATO Gynybos koledže Romoje, NATO Civilių ir kariškių bendradarbiavimo tobulinimo centre, Jungtiniame oro operacijų centre Vedeme (Vokietija), Podžo Renatiko aviacijos bazèje Italijoje ir kt.

Lietuva turiningai bendradarbiauja su Vokietijos Bundesvero generalinio štabo vadų akademija, kuri vaidina labai svarbų vaidmenį rengiant aukšto rango 
Lietuvos karininkus. Generalinio štabo akademiją sudaro mokymo, kursų ir aprūpinimo vienetai. Užsieniečiams čia įrengti du skyriai - vienas priklauso NATO šalių atstovams, kitas - šiam Aljansui nepriklausančių šalių atstovams.

Iki 2005 m. Lietuvos karininkai buvo rengiami LGAI (vok. Lehrgang Generalstabs-/Admiralstabsdienst mit internationaler Beteiligung) ir EURO kursuose. Lietuva dalyvauja LGAI kurse nuo 1993 m. ir EURO kurse nuo 1997 m. LGAI kurso tikslas - parengti užsienio šalių karininkus tarnauti įvairaus lygmens štabuose. Nuo $2005 \mathrm{~m}$. Lietuvos karininkai dalyvauja dvejų metų nacionaliniuose generalinio štabo/admiraliteto kursuose LGAN (vok. Nationaler Lehrgang Generalstabs/ Admiralstabsdienst), kurie skirti tik NATO ir ES šalims.

Ne vienus metus palaikomi draugiški ryšiai su Didžiosios Britanijos, Prancūzijos, Austrijos, Danijos, Skandinavijos šalių, Čekijos, Slovenijos, Lenkijos, Estijos ir Latvijos karo mokyklomis.

Vakaru karo mokyklos rengia kvalifikuotus kuopos, bataliono, štabo vado lygmens karininkus, jie vèliau dar adaptuojasi, gauna pritaikytą Baltijos gynybos sistemai išsilavinimą Baltijos gynybos koledže (Baltic Defence College BALTDEFCOL) Tartu (Estijoje).

İkurti Baltijos gynybos koledžą buvo nuspręsta $1998 \mathrm{~m}$. birželio $12 \mathrm{~d}$. Briuselyje Lietuvos, Latvijos ir Estijos vyriausybėms pasirašius steigimo sutarti. Baltijos gynybos koledžas yra bendra Lietuvos, Latvijos ir Estijos operacinio ir strateginio lygmens karininkų rengimo bei civilių tarnautojų mokymo ịstaiga, įsteigta padedant NATO sajungininkams. Šio projekto autorius - buvęs Danijos gynybos atašè Lietuvai, Latvijai ir Estijai brigados generolas M. H Klemesenas (M. H. Clemmesen).

Koledžo inauguracija ịvyko $1999 \mathrm{~m}$. vasario $25 \mathrm{~d}$. Pirmieji 32 studentai iš aštuonių šalių aukštesniųjų štabo karininkų kurso studijas pradejo $1999 \mathrm{~m}$. rugpjūčio 16 d. $2000 \mathrm{~m}$. birželio 22 d. pirmajai klausytojų laidai buvo įteikti baigimo diplomai, tarp jų ir 8 Lietuvos karininkams.

Šis koledžas vertinamas daugelyje NATO šalių, todèl ten tobulintis siunčiami ne tik Baltijos šalių, bet ir kitų valstybių karininkai. Lietuva taip pat finansuoja Ukrainos, Gruzijos ir Moldovos studentų mokymąsi koledže.

BALTDEFCOL mokymo turinys pritaikytas prie Baltijos regiono geopolitinių ypatumų, turimų karinių pajėgų pobūdžio. Mokymo procese stengiamasi kuo daugiau taikyti NATO procedūras ir standartus. Tai skatina Baltijos valstybių kariuomenių sąveikumą su NATO.

Baltijos gynybos koledžas vykdo penkis mėnesius trunkantị Aukštesniuju vadu kursa, kurio tikslas - parengti karininkus ir civilius tarnautojus vadovauti, inicijuoti ir igyvendinti strateginio lygmens reformas savo šalyse, gebèti tinkamai reaguoti į besikeičiančią saugumo situaciją. Per Jungtinio vadovavimo ir štabo karininku kursa, trunkantị 11 mėnesių, siekiama parengti karininkus vadovaujamoms pareigoms taktiniu lygmeniu bei darbui jungtiniuose štabuose. Civiliu tarnautoju kursas trunka 3 mènesius, jo tikslas - suteikti civiliams tarnautojams žinių ir 
igūdžių, reikalingų igyvendinant ir tobulinant nacionalinę saugumo ir gynybos politiką. Vyresniuju vadovu kursas suteikia galimybę generolo lygio karininkams ir jiems prilygintiems civiliams tarnautojams gauti žinių ir ịḡdžių, reikalingų vykdant aukščiausios atsakomybès reikalaujančias nacionalines ir tarptautines užduotis. Nuo 2019 m. taip pat pradedamas organizuoti Vyriausiuju puskarininkiu kursas.

2000-2020 m. koledžą yra baigę 1582 vyresnieji karininkai ir aukštesniojo lygmens civiliai pareigūnai iš daugiau nei 40 šalių, iš 384 Lietuvos jungtinio vadovavimo ir štabo karininkų kursą baige 241, aukštesniųjų štabo karininkų kursą - 55 . 2019 m. studijas sėkmingai baigè vienas Gruzijos (Sakartvelo) ir du Ukrainos karininkai, kurių studijas koledže finansavo Lietuva. Didžioji dalis Lietuvos karinių dalinių vadų yra baigę ịvairius Baltijos gynybos koledžo kursus.

\section{Išvados}

1. $1990 \mathrm{~m}$. kovo $11 \mathrm{~d}$. paskelbus nepriklausomybę, reikejjo ne tik organizuoti krašto apsaugą, bet ir atgaivinti sovietinès okupacijos metais sužlugdytą Lietuvos karininkų rengimą. Gruodžio 20 d. Lietuvos Respublikos Vyriausybės nutarimu Krašto apsaugos departamento įsteigtuose Karininkų kursuose Kaune buvo perkvalifikuojami praporščikai, jaunesnieji atsargos ir kiti buvę sovietinès kariuomenès karininkai.

2. Tačiau tolesniam karininkų rengimui ir jų kvalifikacijos kèlimui šių kursų nepakako - trūko išsilavinusių, gerai parengtų karininkų - reikejjo nuolat veikiančios karininkų rengimo institucijos. Imta galvoti apie Karo mokyklos atkūrimą. Lietuvos krašto apsaugos ministerijos $1992 \mathrm{~m}$. vasario $25 \mathrm{~d}$. ịsakymu „Dèl Lietuvos aukštosios karo mokyklos ịkūrimo" nuspręsta ịsteigti aukštają karo mokyklą.

3. Per nepriklausomybès laikotarpi buvo sukurta tobula ir efektyviai funkcionuojanti Lietuvos kariuomenès karininkų rengimo ir jų kvalifikacijos kélimo sistema. Svarbiausią vaidmenį rengiant karininkus ir keliant jų kvalifikaciją atliko Generolo Jono Žemaičio Lietuvos karo akademija, taip pat Generolo Adolfo Ramanausko kovinio rengimo centras, Lietuvos kariuomenès Sausumos pajègų Juozo Lukšos mokymo centras, Dr. Jono Basanavičius karo medicinos tarnybos mokymo centras ir kiti daliniai, kurie rūpinasi karininkų kvalifikacija.

4. Lietuvos karininkai sėkmingai mokosi ir tobulinasi užsienio šalių karinėse mokymo institucijose. Svarbų vaidmenį rengiant ir tobulinant Lietuvos karininkus ir civilius tarnautojus atlieka Baltijos gynybos koledžas, kiti įvairūs karo ir gynybos koledžai, vadų ir generalinio štabo karininkų kursai ir kt.

5. Tolesniam karininkų rengimui ir jų kvalifikacijos kèlimui buvo įsteigti ịvairūs specializuoti ilgalaikiai ir trumpalaikiai, nuolatiniai ir laikini kursai. Sėkmingai ir produktyviai veikia Jaunesniujų karininkų vadų mokymai (JKVM). Tokie kursai aukštujų mokyklų studentams buvo rengiami Lietuvos didžiojo kunigaikščio Butigeidžio dragūnų batalione Klaipedoje, Generolo Jono Žemaičio Lietuvos karo akademijoje Vilniuje ir Divizijos generolo Stasio Raštikio puskarininkių 
mokykloje Kaune.

6. Lietuvos kariuomenès karininkai taip pat sėkmingai kèlè kvalifikaciją įvairiose kariuomenès padalinių organizuojamose ir tarptautinèse pratybose ir dalyvaudami kituose kariniuose renginiuose.

7. Krašto apsaugos sistemos stiprinimu, visuomenès parengimu gynybai, karininkų rengimu, jų kvalifikacijos kèlimu taip pat rūpinasi ir Lietuvos nevyriausybinès organizacijos, karininkų ramovès, karinė žiniasklaida ir kt. Ši sistema užtikrina visų lygių karininkų rengimą, formuoja visapusiškai išsilavinusių karininkų korpusą.

\section{Literatūra}

Andriškevičius J., „Nuo Krašto apsaugos mokyklos iki Karo akademijos (1992-1994 m.)“, Vilnius: Generolo Jono Žemaičio Lietuvos karo akademija, 2019, p. $21-22$.

Balaišis A., „Karininkų rengimas Lietuvoje“, Karys, 1996, Nr. 1, p. 23.

Baltic Defence College, [žiūrèta 2020-02-21]. Prieiga per internetą https:// www.baltdefcol.org/?id=45

Budrys K., „I mūšì pakilo kariūnai“, Karys, 1994, Nr. 7, p. 32.

Budrys K., „1994-ųu leitenantai“, Karys, 1994, Nr. 9. p. 2.

Dèl Lietuvos Respublikos Seimo 2002 m. gegužès 28 d. nutarimo Nr. IX-907 „Dèl nacionalinio saugumo strategijos patvirtinimo“ pakeitimo, Vilnius, 2017-0117, Nr. XIII-202, TAR, 2017 m. sausio 25 d., Nr. 1424.

„Didžiuokitès savo profesija ir pšaukimu“, Kariūnas, 2007, Nr. 4 (95), p. 32.

Diržinauskis R., „Tai buvo garbès reikalas“, Kariūnas, 2012, Nr. 2 (113), p. $39-40$.

„Dr. Jono Basanavičiaus karo medicinos tarnyba“, https://kariuomene.kam. 1t/1t/kariuomenes_struktura/logistikos_valdyba/padaliniai_559/dr.jono_basanaviciaus_karo_medicinos_tarnyba.html.

Estijos Respublikos Vyriausybès, Latvijos Respublikos Vyriausybès ir Lietuvos Respublikos Vyriausybès sutartis „Dėl Baltijos gynybos koledžo“, Briuselis, 1998 m. birželio 12 d., Valstybès žinios, 1999-04-21, Nr. 35-1026.

Generolo Jono Žemaičio Lietuvos karo akademija, http://www.lka.lt/1t/titulinis.html

Generolo Jono Žemaičio Lietuvos karo akademijos statutas. Patvirtintas Lietuvos Respublikos Vyriausybės 1999 m. rugpjūčio 10 d. nutarimu Nr. 896. Valstybés žinios, 1999-08-13, Nr. 69-2196.

Generolo Jono Žemaičio Lietuvos karo akademijos statutas. Patvirtintas Lietuvos Respublikos Vyriausybès 1999 m. rugpjūčio 10 d. nutarimu Nr. 896. Valstybés žinios, 1999-08-13, Nr. 69-2196. Suvestinè redakcija nuo 2018-04-14, [žiūrèta 2019-11-12]. Prieiga per internetą: http://www3.1rs.lt/pls/inter3/dokpaieska. showdoc_1?p_id=5704\&p_tr2=2.

„Generolo Adolfo Ramanausko kovinio rengimo centras“, [žiūrèta 2019- 
11-20]. Prieiga per internetą: https://kariuomene.kam.lt/lt/kariuomenes_struktura/ mokymo_ir_doktrinu_valdyba/lk_mokymo_ir_doktrinu_valdyba_sudaro_sie_karinio_mokymo_vienetai/generolo_adolfo_ramanausko_kovinio_rengimo_centras/ tarptautinis_bendradarbiavimas.html

Grigas R., „Tautos savigyna“, Karys, 1993, Nr. 4, p. 8.

Jankauskas P., „Mokosi būsimieji vadai“, Karys, 1994, Nr. 7, p. 31.

Jankūnas A., „Apie teises gali kalbėti tie, kurie atliko pareigą valstybei“, $\mathrm{Ka}$ riūnas, 2012, Nr. 2 (113), p. 41-45.

„Jokių kliūčių bendradarbiauti nėra“, Karys, 1994, Nr. 1, p. 1.

„Karo mokykla laukia naujų kariūnų“, Krašto apsauga. Krašto apsaugos ministerijos savaitraštis, 1993 m. balandžio 8 d., Nr. 13-14 (91-92), p. 7.

Klenauskienė I., Varanavičius D., „Lietuvos kariuomenès mokykla - 25 metai intensyvaus darbo“, Karys, 2015, Nr. 12 (2040), p. 10-11.

Krašto apsaugos ministro įsakymas „Dèl Lietuvos aukštosios karo mokyklos ¡ikūrimo“, Nr. 112, 1992-02-25, Krašto apsaugos ministro ìsakymai, Nr. 222-355, 1992 Nr. 01-479, ats. red. ir sudarytojas G. Surgailis, t. 1, Vilnius: Generolo Jono Žemaičio Lietuvos karo akademija, 2004, p. 175.

Krašto apsaugos ministro įsakymas „Dèl Krašto apsaugos mokyklos įsteigimo“"Nr. 507, 1992-07-13, Krašto apsaugos ministro įsakymai, 1992 Nr. 480-749, ats. red. ir sudar. G. Surgailis, t. 2, Vilnius: Lietuvos Respublikos krašto apsaugos ministerija, Generolo Jono Žemaičio Lietuvos karo akademija, 2006, p. 24-25.

„Kviečiu Lietuvos žmones santarvei ir darbui!“. Mintys iš Lietuvos Respublikos Prezidento Algirdo Brazausko kalbos, pasakytos Seime 1993 m. vasario 25 d., Karys, 1993, Nr. 4, p. 2-3.

Kulys Z., „Lietuvos karo akademija“, Krašto apsauga. Proginis Krašto apsaugos ministerijos laikraštis, 1995 m. balandžio 25 d., Nr. 1 (129), p. 13.

Lietuvos Respublikos Seimas: https://www.lrs.lt/ Lietuvos Respublikos Prezidentas: https://www.lrp.lt/lt

Lietuvos Respublikos krašto apsaugos ministerija, https://kam.lt/lt/titulinis_1220.html

Lietuvos kariuomenè: https://kariuomene.kam.lt/lt/kariuomenes_struktura/ kariuomene_nuo_aiki_z.html

„Lietuvos Respublikos nacionalinio saugumo pagrindų įstatymas“. Vilnius, 1996-12-19. Nr. VIII-49, Valstybès žinios, 1997 m. sausio 8 d., Nr. 2-16, Galiojanti suvestinè redakcija: 2020-01-01 - 2020-06-30 [žiūrèta 2020-02-12]. Prieiga per internetą: https://www.e-tar.lt/portal/lt/legalAct/TAR.A0BAB27D768C/asr

Lietuvos Respublikos Seimo nutarimas „Dèl nacionalinio saugumo strategijos patvirtinimo“, Vilnius, 2002 -05-28, Nr. IX-907, Valstybès žinios, 2002 m. birželio 7 d., Nr. 56-2233.

Lietuvos Respublikos Seimo nutarimas „Dèl nacionalinio saugumo strategijos patvirtinimo“" priedo pakeitimo, 2005-01-20, Nr. X-91, Valstybès žinios, 2005 m. vasario 1 d., Nr. 15-473. 
Lietuvos Respublikos Seimo nutarimas „Dèl nacionalinio saugumo strategijos patvirtinimo“" pakeitimo, Vilnius, 2012-06-26, Nr. XI-2131, Valstybès žinios, 2012 m. birželio 30 d., Nr. 76-3945.

Lietuvos Respublikos Vyriausybės nutarimas, „Dèl Krašto apsaugos departamento karininkų kursų organizacinių klausimų“ Vilnius, $1990 \mathrm{~m}$. gruodžio 20 d., Nr. 384, Valstybès žinios, 1991-01-10, Nr. 1-18.

„Lietuvos Respublikos karinè strategija“. Patvirtinta Lietuvos Respublikos krašto apsaugos ministro $2016 \mathrm{~m}$. kovo $17 \mathrm{~d}$. įsakymu Nr. V-252. [žiūrèta 2019-11-12]. Prieiga per internetą: http://kam.lt/lt/gynybos_politika_490/aktualus_ dokumentai_492/strateginiai_dokumentai_494.html

Lietuvos Respublikos Vyriausybès nutarimas „Dèl Krašto apsaugos akademijos steigimo“, Vilnius, 1992 m. birželio 16 d., Nr. 460, Lietuvos aidas, 1992 m. birželio 17 d, Nr. 117-0.

Lietuvos Respublikos Seimo nutarimas „Dèl Lietuvos karo akademijos įsteigimo“, Vilnius, 1994-01-18, Nr. I-371, Valstybès žinios, 1994 m. sausio 26 d., Nr. 7-10.

Lietuvos Respublikos Seimo nutarimas „Dèl Lietuvos karo akademijos statuto“, Vilnius, 1994-05-26, Nr. I-479, Valstybès žinios, 1994 m. birželio 8 d., Nr. 43 783 .

Lietuvos Respublikos ministro pirmininko potvarkis „Dèl pirmojo karininko laipsnio suteikimo“, Vilnius, 1994 m. rugpjūčio 2 d., Nr. 455P [žiūrèta 2019-11-29]. Prieiga per internetą: https://www.e-tar.lt/portal/lt/legalAct/TAR.633BE4C3E39B

Lietuvos Respublikos Seimo Lietuvos Respublikos nacionalinio saugumo pagrindų įstatymas, 1996 m. gruodžio 19 d. Nr. VIII-49, Vilnius, Valstybès žinios, 1997-01-08, Nr. 2-16.

Lietuvos Respublikos krašto apsaugos sistemos organizavimo ir karo tarnybos ịstatymas, Vilnius, 1998 m. gegužès 5 d., Nr. VIII-724, Valstybès žinios, 1998-05-27, Nr. 49-1326.

Lietuvos Respublikos karo prievolès įstatymas, Vilnius, 1996, m. spalio 22 d., Nr. I-1593, Valstybès žinios, 1996-11-06, Nr. 106-2427. Galiojanti suvestinè redakcija (nuo 2019-01-01) [žiūrèta 2019-11-20]. Prieiga per internetą: https:// www.e-tar.lt/portal/lt/legalAct/TAR.E9CE9C91C255/asr

Lietuvos Respublikos krašto apsaugos sistemos organizavimo ir karo tarnybos ịstatymas, Vilnius, 1998 m. gegužès 5 d., Nr. VIII-723, Valstybès žinios, 1998-05-27, Nr. 49-1325. Suvestinè redakcija nuo 2019-09-01 iki 2019-12-31 [žiūrèta 2019-11-20]. Prieiga per internetą: https://www.e-tar.lt/portal/lt/legalAct/ TAR.15C705E93776/asr

Lietuvos Respublikos Prezidento Algirdo Brazausko pareiškimas „Dẻl Lietuvos narystès NATO“, Vilnius, 1994-01-04, Lietuvos Respublikos Aukščiausiosios Tarybos ir Lietuvos Respublikos Aukščiausiosios Tarybos Prezidiumo dokumentu rinkinys, Vilnius: Valstybinis leidybos centras, t. 3(9), 1994, p. 549-550.

Starinskas K., „Dèl vietos po NATO skèčiu“, Karys, 1994, Nr. 2, p. 3-4. 
„Steigiamasis karininkų susirinkimas.1993 m. balandžio 2 d.“, Krašto apsauga. Krašto apsaugos ministerijos savaitraštis, $1993 \mathrm{~m}$. balandžio 8 d., Nr. 13-14 (91-92), p. 1, 4-5.

„Sausumos pajègų Juozo Lukšos mokymo centras (SP JLMC)“ [žiūrèta 2019-11-20]. Prieiga per internetą: https://kariuomene.kam.lt/lt/kariuomenes_ struktura/sausumos_pajegos/padaliniai/spjlmc.html

Stonys V., „Kad kariuomenè būtų matoma ir gerbiama. Lietuvos karininkų susirinkimas“, Karys, 1994, Nr. 9, p. 4-5.

Surgailis G., „Antrojo gimtadienio proga“, Karys, 1992, Nr. 4, p. 4.

Surgailis G., „Lietuvos karo akademija per 10 metų“, Krašto apsauga, 2002-06-07 - 06-13, Nr. 12 (15), p. 3.

Šarkus T., „Su pirmaisiais mokslo metais, kariūnai! Atidaryta Karo mokykla Vilniuje“, Karys, 1992, Nr. 9, p. 6.

Šarkus T., „Sunkus kelias ị karininko profesiją. Pokalbis su Karo mokyklos dèstytojais“, Karys, 1993, Nr. 3, p. 8-9.

Vaitkaitis A., „Karininkų rengimas atkūrus Lietuvos nepriklausomybę (1990-1992 metai)“, Karys, 2012, Nr. 5 (1998), p. 10-12.

„Vèl kviečia Karo mokykla“, Karys, 1992, Nr. 6, p. 3.

Vizbaras B., „Puskarininkių mokykla“, Krašto apsauga. Proginis Krašto apsaugos ministerijos laikraštis, 1995 m. balandžio 25 d., Nr. 1 (129), p. 13.

Voveris V., „Kariūnai“, Krašto apsauga. Krašto apsaugos ministerijos savaitraštis, 1993 m. balandžio 23, Nr. 15-18 (93-96), p. 3. 


\title{
LITHUANIAN MILITARY OFFICERS' TRAINING \\ IN THE PERIOD OF 1990-2020
}

\author{
Assoc. Prof. Dr. Feliksas Žigaras
}

\begin{abstract}
Summary
During the Independence period, a perfect and effectively functioning Lithuanian military officers' training system was developed. The General Jonas Žemaitis Military Academy of Lithuania, General Adolfas Ramanauskas Warfare Training Centre, Juozas Lukša Land Forces Training Center, MD Jonas Basanavičius Military Medical Service, Lithuanian Navy Training Center in Klaipeda and other units of the Lithuanian Armed Forces have been playing the biggest role in military officers' training and training system development.

Lithuanian military officers successfully study and train at foreign military education institutions. The Baltic Defence College and other military and defence colleges, courses for commanders and general staff officers assume a great role in training Lithuanian military and civil officers.

Various long-term and short-term, continuous and temporary courses were established for further military officers' training. The courses for younger military commanders are successful and productive. Such courses for higher school students have been organized at the Lithuanian Grand Duke Butigeidis Dragoon Battalion in Klaipeda, The General Jonas Žemaitis Military Academy of Lithuania in Vilnius and Division General Stasys Raštikis Lithuanian Armed Forces School in Kaunas.

The Lithuanian Union of Reserve Officers, officers' clubs, military press and others also participate in the training process. The system ensures military officer training of all levels and forms comprehensively educated military corps.
\end{abstract}




\section{AUTORIAUS LYDRAŠTIS}

Autoriaus vardas, pavardè: Feliksas Žigaras

Mokslo laipsnis ir vardas: docentas, daktaras

Darbo vieta ir pareigos

Autoriaus mokslinių interesų sritys: Lietuvos tarptautinis bendradarbiavimas; Lietuvos, Latvijos ir Estijos santykiai; pilietinio ugdymo raida, patirtis, Lietuvos kariuomenès problemos, jų sprendimo būdai; Lietuvos kariuomenès karininkų rengimas (1919-1940 m.); Lietuvos kariuomenès karininkų rengimas (1990-2020 m.)

Telefonas ir el. pašto adresas: +37061284 775;

feliksas.zigaras@yahoo.com

\section{AUTHOR'S COVER LETTER}

Author's name and surname: Feliksas Žigaras Academic degree and name: Associate Professor, Doctor

Author's research interests: international cooperation of Lithuania, relationship among Lithuania, Latvia and Estonia, development of civic education, experience and problems of the Lithuanian Armed Forces and their solutions, Lithuanian officer training in the period of 1919-1940, Lithuanian officer training system and its development in the period of 1990-2020

Telephone and e-mail address: +37061284775 ;

feliksas.zigaras@yahoo.com 